\title{
Antimicrobial actions of dual oxidases and lactoperoxidase
}

\author{
Demba Sarr, Eszter Tóth, Aaron Gingerich, \\ and Balázs Rada* \\ Department of Infectious Diseases, College of Veterinary Medicine, \\ University of Georgia, Athens GA, USA \\ (Received Dec 15, 2017 / Revised Feb 16, 2018 / Accepted Feb 19, 2018)
}

The NOX/DUOX family of NADPH oxidases are transmembrane proteins generating reactive oxygen species as their primary enzymatic products. NADPH oxidase (NOX) 1-5 and Dual oxidase (DUOX) 1 and 2 are members of this family. These enzymes have several biological functions including immune defense, hormone biosynthesis, fertilization, cell proliferation and differentiation, extracellular matrix formation and vascular regulation. They are found in a variety of tissues such as the airways, salivary glands, colon, thyroid gland and lymphoid organs. The discovery of NADPH oxidases has drastically transformed our view of the biology of reactive oxygen species and oxidative stress. Roles of several isoforms including DUOX1 and DUOX2 in host innate immune defense have been implicated and are still being uncovered. DUOX enzymes highly expressed in the respiratory and salivary gland epithelium have been proposed as the major sources of hydrogen peroxide supporting mucosal oxidative antimicrobial defenses. In this review, we shortly present data on DUOX discovery, structure and function, and provide a detailed, upto-date summary of discoveries regarding antibacterial, antiviral, antifungal, and antiparasitic functions of DUOX enzymes. We also present all the literature describing the immune functions of lactoperoxidase, an enzyme working in partnership with DUOX to produce antimicrobial substances.

Keywords: dual oxidase, lactoperoxidase, DUOX, LPO, antimicrobial, NADPH oxidase

\section{Introduction: NADPH oxidases}

The family of NADPH oxidases is composed of DUOX1/2 and five additional NOX enzymes: NOX1-5 (Dupuy et al., 1999; De Deken et al., 2000; Bokoch and Knaus, 2003; Lambeth, 2004; Lambeth and Neish, 2014) that generate reactive oxygen species (ROS) as primary products of their enzyma-

\footnotetext{
${ }^{*}$ For correspondence. E-mail: radab@uga.edu; Tel.: +1 706 5423695; Fax: $+17065425771$

Copyright (c) 2018, The Microbiological Society of Korea
}

tic activities (Lambeth, 2004; Grasberger and Refetoff, 2006; Lambeth and Neish, 2014). A conserved catalytic core responsible for transmembrane electron transfer from the intracellular electron donors to the extracellular compartment to generate superoxide or hydrogen peroxide characterizes this family of enzymes (De Deken et al., 2014). Under normal conditions, most NOX isoforms have very low or no constitutive activity but their expression can be high in disease states. In these disease conditions, the activation of NOX isoforms generates high levels of ROS that can overwhelm the antioxidant system, leading to increased oxidative stress. Oxidative stress is defined as the increase of reduction potential or a large decrease in the reducing capacity of cellular redox couples (Genestra, 2007). In other words, oxidative stress occurs when the production of ROS exceeds the capacity of antioxidant defenses leading to harmful effects on the function and structural integrity of biological tissues. ROS can trigger rapid chain reactions and cause damage to macromolecules such as lipids, proteins, carbohydrates, and nucleic acids [reviewed by (Roy et al., 2017)]. They are believed to be toxic by-products that can cause cellular stress, aging, damage, and cancer (Harman, 1956, 1981; Liu et al., 2004). However, several lines of evidence suggest that ROS generation is an important process of the host innate immune system by promoting killing of invading microorganisms (Rada and Leto, 2008; van der Vliet, 2008; Gattas et al., 2009; Lipinski et al., 2009), and NOX-derived ROS are associated with inflammation [reviewed by (Mittal et al., 2014)]. ROS have been shown to play a role in antimicrobial defenses, and the role of DUOX-derived ROS in innate immune responses against many bacterial, viral, and parasitic infections has been shown. The primary role of the DUOX1 and DUOX2, as well as, the five other NOX proteins (NOX 1-5) is the production of ROS in a wide range of organisms (Geiszt and Leto, 2004; Bedard and Krause, 2007; Bedard et al., 2007; Lambeth and Neish, 2014). While NOX enzymes secrete both, superoxide and hydrogen peroxide as primary products, DUOX proteins generate hydrogen peroxide $\left(\mathrm{H}_{2} \mathrm{O}_{2}\right)$ (Bjorkman and Ekholm, 1984; Dupuy et al., 1989). DUOX enzymes have been implicated in a vast array of biological processes including hormone synthesis, fertilization, cell differentiation, cell proliferation, cell death, extracellular matrix formation, vascular regulation, angiogenesis, and host defense mechanisms (Geiszt and Leto, 2004; Lambeth, 2004; Bedard and Krause, 2007; Bedard et al., 2007; Lipinski et al., 2009; Panday et al., 2015; Chen et al., 2017; Kim et al., 2017; Mistry and Brewer, 2017; Prieto-Bermejo and HernandezHernandez, 2017; Ryu et al., 2017). Production of $\mathrm{H}_{2} \mathrm{O}_{2}$ by 
NADPH oxidases was thought to be restricted to phagocytes (macrophages and neutrophils) in host defense (Segal, 2005). Later on, however, NADPH oxidase-mediated production of $\mathrm{H}_{2} \mathrm{O}_{2}$ has been demonstrated in a number of non-phagocytic cells. A recent review has thoroughly analyzed the NOX/DUOX family of NADPH oxidase with lessons learned from knockout mouse models (Sirokmany et al., 2016). Other recent reviews have highlighted the implication of NADPH oxidases in different biological systems including their potential as drug targets and biomarkers in neurodegenerative diseases and their involvement in vascular biology (Jha et al., 2017; Li and Pagano, 2017; Little et al., 2017; Prieto-Bermejo and Hernandez-Hernandez, 2017; Sorce et al., 2017; Wang and Hartnett, 2017).

\section{DUOX discovery}

DUOX enzymes are expressed in several tissues and cell types. The generation of ROS by dual oxidases is a crucial step in tyrosine-crosslinking of extracellular matrix, in the fertilization envelope, innate immunity, wound healing, and thyroid hormone biosynthesis (Dupuy et al., 1999; De Deken et al., 2000, 2014; Edens et al., 2001; Wong et al., 2004; Ha et al., 2005; Grasberger et al., 2007; Chavez et al., 2009; Lipinski et al., 2009; Niethammer et al., 2009; Fortunato et al., 2010; Kumar et al., 2010; Song et al., 2010; Hoeven et al., 2011; Moribe et al., 2012; Moribe and Mekada, 2013; van der Hoeven et al., 2015). The DUOX1 and DOUX2 genes, previously called THOX 1 and THOX2, respectively, were cloned for the first time in human and porcine thyroid gland (Dupuy et al., 1999; De Deken et al., 2000). DUOX1 is the main NADPH oxidase expressed in uroepithelial cells possibly participating in the mechanosensory mechanism of the bladder (Donko et al., 2010). In 2001, Edens et al. (2001) reported the cloning of homologous sequences from Caenorhabditis elegans, a free-living transparent nematode that lives in soil environment. Both DUOX isoforms are highly expressed in tracheobronchial epithelial cells and in the thy- roid gland (Dupuy et al., 1999; De Deken et al., 2000; Geiszt et al., 2003; Harper et al., 2005; Harper et al., 2006). Predominant expression of DUOX1 was found in the respiratory epithelium while DUOX2 is mostly present in the thyroid gland, the salivary and rectal gland epithelia (Geiszt et al., 2003). In airway epithelia, DUOX1 expression is enhanced during epithelial cell differentiation and alveolar maturation (Fischer et al., 2007). DUOX2 is also expressed in the surface epithelia of the lung and the intestine (Geiszt et al., 2003; El Hassani et al., 2005). Expression of DUOX2 has been found elevated in patients with Crohn's disease and in response to Helicobacter pylori infections (Szanto et al., 2005; Csillag et al., 2007; Rokutan et al., 2008). Using laser capture microdissection followed by real time quantitative PCR, researchers have found that DUOX2 is predominantly expressed in the tip epithelium of the ileum and colon (Sommer and Backhed, 2015). Here, the expression of DUOX2 in both tissues was induced by a normal microbiota. In the ileum, DUOX2 expression induced by normal microbiota involved NF-B signaling while colonic expression was mediated through MyD88 and p38 MAPK (Sommer and Backhed, 2015).

\section{DUOX structure}

Edens et al. (2001) suggested a DUOX nomenclature based on the structural features of the protein. The characteristic features of DUOX enzymes have been thoroughly reviewed by Donko et al. (2005). DUOX genes are located on the human chromosome 15, where they are arranged in a headto-head configuration, separated by a $16 \mathrm{~kb}$ region (Pachucki et al., 2004). DUOX1 gene shares $83 \%$ similarity with DUOX2 gene. The size of DUOX1 is $36 \mathrm{~kb}$ with 35 exons while DUOX2 measures $22 \mathrm{~kb}$ and contains 34 exons. Structurally, both human DUOX isoforms share a conserved motif, consisting of an N-terminal peroxidase like domain, two calciumbinding sites, six transmembrane domains, and an NADPH oxidase domain. Consistent with this motif, calcium was shown to regulate the production of ROS by both, DUOX1

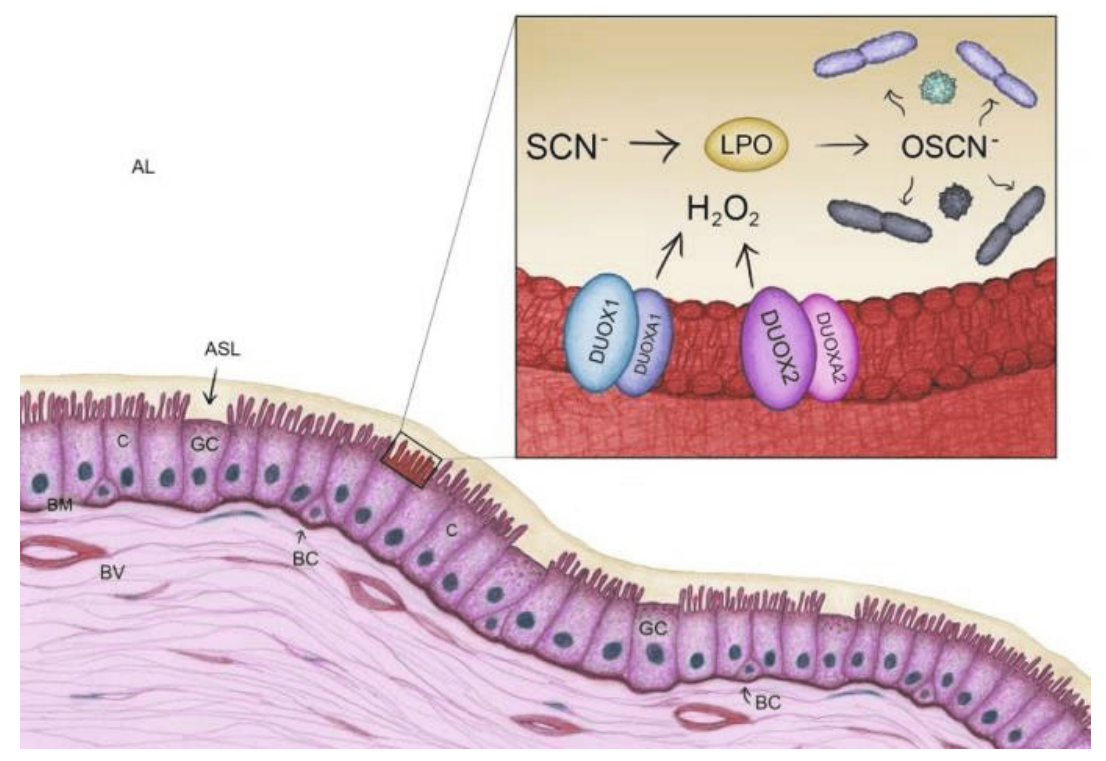

Fig. 1. Model of the DUOX/ $/ \mathrm{H}_{2} \mathrm{O}_{2} / \mathrm{LPO} / \mathrm{SCN}^{-}$antimicrobial system in the respiratory tract. Ciliated (C) airway epithelial cells express DUOX1/DUOXA1 and DUOX2/DUOXA2 complexes in their luminal/ apical plasma membrane producing $\mathrm{H}_{2} \mathrm{O}_{2}$ into the airway surface liquid (ASL). Lactoperoxidase (LPO) uses this $\mathrm{H}_{2} \mathrm{O}_{2}$ to oxidize its main substrate, thiocyanate $\left(\mathrm{SCN}^{-}\right)$present in large quantities in the ASL into antimicrobial hypothiocyanite $\left(\mathrm{OSCN}^{-}\right) . \mathrm{AL}$, airway lumen; BC, basal cell; BV, blood vessel; GC, Goblet cell. 
and DUOX2 (Ameziane-El-Hassani et al., 2005; Rigutto et al., 2009). Rigutto et al. (2009) provided evidence that the basal activity of both DUOX enzymes depends on calcium and functional EF-hand motifs. They showed with an optimized functional assay that the two oxidases are differentially regulated by activation of separate intracellular signaling cascades (Rigutto et al., 2009). While DUOX1 is stimulated by forskolin via protein kinase A-mediated phosphorylation on serine 955, in contrast, DUOX2 phosphorylation in induced by phorbol esters via protein kinase $\mathrm{C}$ activation associated with high $\mathrm{H}_{2} \mathrm{O}_{2}$ generation (Rigutto et al., 2009). These results were obtained in vitro and await in vivo confirmatory studies. Additional works have highlighted the importance of conserved cysteine residues that are localized in the $\mathrm{N}$-terminal domain in enzymatic maturation, independent of structural stabilization (Morand et al., 2004; Meitzler et al., 2013). Intermolecular disulfide bonds support protein interaction between the DUOX enzymes and their maturations factors indicating the complexity of these enzymes (Meitzler et al., 2013). Both DUOX proteins work in partnership and mature with helper proteins called DUOX activators or maturation factors (Fig. 1) (Grasberger and Refetoff, 2006; Morand et al., 2009). DUOX activators (DUOXA1, DUOXA2) dictate maturation, subcellular localization, and the type of ROS produced by establishing stable complexes with DUOX enzymes (Leto et al., 2009; Morand et al., 2009; Hoste et al., 2012; Donko et al., 2014; Ueyama et al., 2015). Intramolecular disulfide bonds in DUOX2 govern its oxidative folding in the endoplasmic reticulum and subsequent covalent interactions with its maturation factor, DUOXA2 (Carre et al., 2015).

\section{Thyroid functions of DUOX}

The main function of the DUOX2 isoform has been identified in the thyroid follicle, which is the functional structure responsible for the thyroid hormone biosynthesis, storage, and secretion (Dupuy et al., 1999; De Deken et al., 2000; Ohye and Sugawara, 2010). Follicular thyroid cells are polarized and specialized in the production of thyroxine and triiodothyronine. The first step in thyroid hormone biosynthesis corresponds to the iodination of tyrosyl residues of thyroglobulin, a thyroid-specific protein, synthesized and secreted into the follicular lumen. The iodination reaction is believed to occur at the apical membrane of the cells and the colloid interface [reviewed in (Carvalho and Dupuy, 2013)]. The process involves a number of chemical reactions such as iodide oxidation, tyrosyl radical oxidation, thyroglobulin iodination also named iodine organification, and finally coupling of iodotyrosines to form the thyroid hormone [reviewed by (Carvalho and Dupuy, 2013)]. During thyroid hormone biosynthesis, the enzymatic reactions that involve the oxidation of substrate depends on the presence of $\mathrm{H}_{2} \mathrm{O}_{2}$ and an enzyme that catalyzes the process named thyroperoxidase. In the thyrocyte, $\mathrm{H}_{2} \mathrm{O}_{2}$ necessary for hormone biosynthesis is generated at the apical surface through a controlled reaction catalyzed by DUOX2 (Bjorkman and Ekholm, 1984; Virion et al., 1984). Human patients with impaired DUOX2mediated $\mathrm{H}_{2} \mathrm{O}_{2}$ production and DUOX2-deficient mice are hypothyroid (Johnson et al., 2007; Grasberger et al., 2012; Carvalho and Dupuy, 2013; Weber et al., 2013; Donko et al., 2014). Several excellent reviews focused on the thyroid consequences of DUOX2 deficiency (Grasberger, 2010; De Deken et al., 2014; Muzza and Fugazzola, 2017; Targovnik et al., 2017). In the present review, we exclusively focus on roles of DUOX1 and DUOX2 in host defense.

\section{Antimicrobial effects of DUOX and LPO}

In a landmark study, Geiszt and Leto (2003) demonstrated the presence of DUOX in respiratory and gastrointestinal tract, where expression patterns are consistent with presence of LPO and a host defense function. This work put DUOX proteins as the physiological $\mathrm{H}_{2} \mathrm{O}_{2}$ sources into the model of the LPO-based antimicrobial system (Fig. 1) (Geiszt et al., 2003). DUOX proteins generate $\mathrm{H}_{2} \mathrm{O}_{2}$ on the extracellular side of the apical membrane of the airway epithelium (Fig. 1) (Geiszt and Leto, 2004; Schwarzer et al., 2004; Forteza et al., 2005; Shao and Nadel, 2005). $\mathrm{H}_{2} \mathrm{O}_{2}$ is then metabolized by lactoperoxidase (LPO) (Salathe et al., 1997; El-Chemaly et al., 2003) to oxidize thiocyanate ( $\left.\mathrm{SCN}^{-}\right)$into the potent microbicidal molecule hypothiocyanite $\left(\mathrm{OSCN}^{-}\right)$(Fig. 1) (Reiter, 1978; Thomas and Aune, 1978a, 1978b; Carlsson et al., 1984; Ihalin et al., 1998; Conner et al., 2007; Moskwa et al., 2007; Rada and Leto, 2008).

Additionally, complex interactions between NOX/DUOX enzymes and Toll-like receptors have been shown (TLRs) (Asehnoune et al., 2004; Kawahara et al., 2004; Park et al., 2004, 2006). For example, IL-8 expression and reactive oxygen species generation is linked with interactions between DUOX2 and TLR5 (Joo et al., 2012) and between DUOX1 and TLRs (Boots et al., 2009). Using real-time PCR in primary respiratory tract epithelial cultures after treatment with multiple cytokines, DUOX1 mRNA expression was increased several-folds with Th2-cytokines (IL-4 and IL-13), whereas DUOX2 expression was highly induced following treatment with the Th1 cytokine IFN $\gamma$ suggesting regulation of DUOX expression by immunomodulatory cytokines (Harper et al., 2005). Recent works have demonstrated that autophagy promotes an increase in intracellular superoxide levels by regulating DUOX1 during Th2 inflammation of the airway epithelium (Dickinson et al., 2018). This study demonstrated the relationship between autophagy and ROS in airway epithelial cells and implicated DUOX1 in disease pathogenesis (Dickinson et al., 2018).

Thus, several studies have revealed that the human and mammalian airway mucosa contains an oxidative defense mechanism (Gerson et al., 2000; Conner et al., 2002, 2007; Geiszt et al., 2003; Wijkstrom-Frei et al., 2003; Forteza et al., 2005). The three-component system consists of $\mathrm{H}_{2} \mathrm{O}_{2}-$ producing enzyme DUOX1 and DUOX2, the substrate $\mathrm{SCN}^{-}$ and secreted LPO (Geiszt et al., 2003). The LPO-catalyzed reaction between $\mathrm{H}_{2} \mathrm{O}_{2}$ and $\mathrm{SCN}^{-}$leads to the formation of OSCN" (Klebanoff and Luebke, 1965; Klebanoff et al., 1966; Bjorck et al., 1975), which has demonstrated antimicrobial effects (Fig. 1). Table 1 shows a summary of studies implicating DUOX/ $\mathrm{H}_{2} \mathrm{O}_{2}$ and LPO in antimicrobial functions. 
Table 1. Studies on the microbicidal or microbistatic action of the DUOX/ $/ \mathrm{H}_{2} \mathrm{O}_{2} / \mathrm{LPO}$ system

Published reports are organized according to microbial class in alphabetical order of names of the microorganisms. LPO, lactoperoxidase; MPO, myeloperoxidase; NE, nasal epithelial cells; TBE, tracheobronchial epithelial cells.

\begin{tabular}{|c|c|c|}
\hline \multicolumn{3}{|c|}{ Antibacterial action } \\
\hline Bacterial species & Experimental system & References \\
\hline Actinobacillus actinomycetemcomitans & Cell-free system: different LPO and MPO substrates & Ihalin et al. $(1998,2003)$ \\
\hline Aeromonas hydrophila & Cell-free system & Benoy et al. (2000) \\
\hline Bacillus cereus & Cell-free system: different LPO and MPO substrates & Tenovuo et al. (1985) \\
\hline Borrelia burgdorferi & Ixodes scapularis ticks & Yang et al. (2014) \\
\hline Burkholderia cepacia & Human TBE cells & Wijkstrom-Frei et al. (2003), Rada et al. (2008) \\
\hline Capnocytophaga ochracea & \multirow{3}{*}{ Cell-free system } & Courtois et al. (1992) \\
\hline Citrobacter freundi & & Benoy et al. (2000) \\
\hline Eikenella corrodens & & Courtois et al. (1992) \\
\hline Enterococcus faecalis & C. elegans & Chavez et al. (2009), Hoeven et al. (2011) \\
\hline Erwinia carotovora & Drosophila gut & Ha et al. $(2005,2009 b)$ \\
\hline Escherichia coli & Cell-free system, Guinea pig milk and saliva & $\begin{array}{l}\text { Bjorck et al. (1975), Thomas and Aune (1978b), } \\
\text { Stephens et al. (1979), Marshall and Reiter (1980), } \\
\text { Grieve et al. (1992), Benoy et al. (2000), Bosch et al. (2000) }\end{array}$ \\
\hline Eubacterium yurii & \multirow{4}{*}{-Cell-free system } & \multirow{2}{*}{ Courtois et al. (1992) } \\
\hline Fusobacterium nucleatum & & \\
\hline Haemophilus influenzae & & Wijkstrom-Frei et al. (2003) \\
\hline Klebsiella pneumoniae & & Benoy et al. (2000) \\
\hline Listeria monocytogenes & $\begin{array}{l}\text { HEK293, Caco-2 cells: DUOX2 transfection, } \\
\text { DUOX2 siRNA }\end{array}$ & Lipinski et al. (2009) \\
\hline Pasteurella haemolytica & Infection in sheep airways & Gerson et al. (2000) \\
\hline Peptostreptococcus micros & \multirow{3}{*}{ Cell-free system } & \multirow{2}{*}{ Courtois et al. (1992) } \\
\hline Prevotella intermedia & & \\
\hline Proteus mirablis & & Benoy et al. (2000) \\
\hline Pseudomonas aeruginosa & $\begin{array}{l}\text { Cell-free system, human and rat TBE cells, } \\
\text { human airway secretions, ALX-109, C. elegans }\end{array}$ & $\begin{array}{l}\text { Benoy et al. (2000), Bosch et al. (2000), Wijkstrom-Frei et al. } \\
\text { (2003), Conner et al. (2007), Moskwa et al. (2007), Rada et } \\
\text { al. (2008), Gattas et al. (2009), Hoeven et al. (2011), } \\
\text { Moreau-Marquis et al. (2015) }\end{array}$ \\
\hline Pseudomonas fluorescens & Cell-free medium, raw milk & Bjorck et al. (1975) \\
\hline Salmonella enterica typhi & \multirow{6}{*}{-Cell-free system } & Benoy et al. (2000) \\
\hline Salmonella enteritidis & & Benoy et al. (2000), Touch et al. (2004) \\
\hline Salmonella schottmuelleri & & \multirow{4}{*}{ Benoy et al. (2000) } \\
\hline Serratia marcescens & & \\
\hline Shigella dysenteriae & & \\
\hline Shigella sonnei & & \\
\hline Staphylococcus aureus & Cell-free system, Rat TBE cells & Benoy et al. (2000), Bosch et al. (2000), Moskwa et al. (2007) \\
\hline Staphylococcus citreus & \multirow{8}{*}{ Cell-free system } & Benoy et al. (2000) \\
\hline Streptococcus agalactiae & & Mickelson (1979), Mickelson and Anderson (1984) \\
\hline Streptococcus gordonii & & Ashby et al. (2009) \\
\hline Streptococcus lactis & & Marshall and Reiter (1980) \\
\hline Streptococcus mutans & & $\begin{array}{l}\text { Tenovuo and Knuuttila (1977a, 1977b), Soukka et al. (1991), } \\
\text { Thomas et al. (1994), Ashby et al. (2009), Welk et al. (2009) }\end{array}$ \\
\hline Streptococcus sanguinis & & Welk et al. (2009) \\
\hline Streptococcus sobrinus & & Thomas et al. (1994) \\
\hline Vibrio cholerae & & Benoy et al. (2000) \\
\hline & Antiviral action & \\
\hline Viral species & Experimental system & References \\
\hline Adenovirus & Cell-free system, Human and porcine TBE cells & Mikola et al. (1995), Fischer et al. (2011) \\
\hline Echovirus 11 & \multirow{3}{*}{ Cell-free system } & Mikola et al. (1995) \\
\hline HIV & & Pourtois et al. (1990) \\
\hline HSV 1 & & Mikola et al. (1995) \\
\hline H1N1 Influenza A virus & Cell-free system, DUOX2 KO mice, Human NE cells & $\begin{array}{l}\text { Kim et al. (2013), Cegolon et al. (2014), Strengert et al. (2014), } \\
\text { Kim et al. (2015) }\end{array}$ \\
\hline H1N2 Influenza A virus & Rat TBE cells & Gingerich et al. (2016) \\
\hline RSV & Cell-free system, Human and porcine TBE cells & $\begin{array}{l}\text { Fischer et al. (2011), Derscheid et al. (2014), El-Fakharany et al. } \\
(2017)\end{array}$ \\
\hline
\end{tabular}




\begin{tabular}{|c|c|c|}
\hline \multicolumn{3}{|c|}{ Antifungal action } \\
\hline Fungal species & Experimental system & References \\
\hline Alternaria sp. & \multirow{12}{*}{ Cell-free system } & \multirow{2}{*}{ Benoy et al. (2000) } \\
\hline Aspergillus flaws & & \\
\hline Aspergillus niger & & Popper and Knorr (1997), Benoy et al. (2000) \\
\hline Byssochlamys fulva & & Popper and Knorr (1997) \\
\hline Candida albicans & & $\begin{array}{l}\text { Lenander-Lumikari (1992), Majerus and Courtois (1992), } \\
\text { Bosch et al. (2000), Welk et al. (2009), Ahariz and Courtois } \\
\text { (2010), Kho et al. (2012) }\end{array}$ \\
\hline Corynespora cassiicola & & \multirow{3}{*}{ Benoy et al. (2000) } \\
\hline Claviceps sp. & & \\
\hline Corticium salmonicolor & & \\
\hline Mucor rouxii & & Popper and Knorr (1997) \\
\hline Pencillium chrysogeum & & \multirow{2}{*}{ Benoy et al. (2000) } \\
\hline Phytopthora meadii & & \\
\hline Rhodutorula rubra & & \multirow{2}{*}{ - Popper and Knorr (1997), Ha et al. (2009a, 2009b) } \\
\hline Saccharomyces cerevisiae & Cell-free system, Drosophila gut & \\
\hline Trichoderma sp. & Cell-free system & Benoy et al. (2000) \\
\hline \multicolumn{3}{|c|}{ Antiparasitic action } \\
\hline Parasitic species & Experimental system & References \\
\hline Plasmodium falciparum & Cell-free system & Malhotra et al. (1988) \\
\hline Plasmodium berghei & Anopheles gambiae midgut & Kumar et al. (2010) \\
\hline Toxoplasma gondii & Cell-free system: LPO/I, tachyzoite & Tanaka et al. (2006) \\
\hline
\end{tabular}

\section{LPO and thiocyanate}

LPO is a member of the mammalian heme peroxidase family whose members are best known for their antimicrobial activities (Bafort et al., 2014). LPO is a major antimicrobial protein found in milk, saliva, tears and airway secretions (Allen and Morrison, 1966; Goldman and Smith, 1973; Conner et al., 2002; Wijkstrom-Frei et al., 2003). Other members of this family are myeloperoxidase expressed in neutrophils and macrophages, and eosinophil peroxidase found in eosinophils (Davies et al., 2008; Nauseef, 2018). LPO is a glycoprotein that consists of a single polypeptide chain (around 80 $\mathrm{kDa}$ ) containing calcium and iron, and is found in the se-

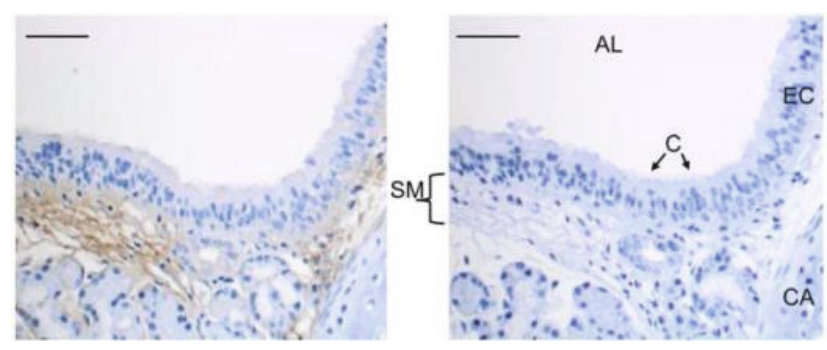

Fig. 2. Submucosal tissue localization of lactoperoxidase in mouse trachea. Trachea of 6-8 week-old C57BL/6J mice were fixed in 4\% paraformaldehyde, embedded in paraffin and subjected to immunohistochemistry to detect lactoperoxidase (LPO). Tracheal sections were blocked with Dako Protein Block (serum-free, code \#X0909) before probing with primary mouse LPO antibody (Novus Biological, cat\#: NBP1-87010, 1/500, rabbit) followed by horseradish peroxidase-labelled secondary anti-rabbit antibody (GBI Labs, Polymer HRP anti-rabbit IgG, cat\#: D13-18). Brown staining indicative of LPO localization was developed with $3,3^{\prime}$-diaminobenzidine substrate (left panel). In the right panel the LPO antibody was omitted. Bar indicates $20 \mu \mathrm{m}$. AL, airway lumen; C, cilia; CA, cartilage; EC, epithelial cells; SM, submucosa. One representative result, $\mathrm{n}=5$. cretions of exocrine glands (Bafort et al., 2014). LPO in the airways is synthesized and secreted by submucosal glands and by the airway epithelium and comprises one percent of the total protein content in the airway surface liquid (Salathe et al., 1997). LPO has been detected previously in human and sheep airways but no data indicated its presence in the murine respiratory tract. We performed immunohistochemistry and detected LPO expression in submucosal tissues, as expected, in murine trachea, as well (Fig. 2). LPO uses hydrogen peroxide to catalyze the oxidation of its preferred halide substrates including $\mathrm{I}^{-}, \mathrm{Br}^{-}, \mathrm{F}^{-}$, or the pseudohalide $\mathrm{SCN}^{-}$(Bafort et al., 2014). Based on the second-order rate constants of the reaction between LPO Compound I and its (pseudo) halide substrate, $\mathrm{SCN}^{-}$is the preferred substrate of LPO followed by I', Br', and $\mathrm{Cl}^{-}$(Bafort et al., 2014).

Thiocyanate $\left(\mathrm{SCN}^{-}\right)$is a pseudohalide thiolate that is universally found in extracellular fluids including saliva, plasma, airway surface liquid (ASL), milk, tears, and gastric juices of mammals (Chandler and Day, 2012). The concentration at which $\mathrm{SCN}^{-}$is present is variable and can range from 0.01-3 mM, but in the airway surface liquid the SCN ${ }^{-}$concentration is estimated to be around $0.4 \mathrm{mM}$ (WijkstromFrei et al., 2003; Chandler and Day, 2012). SCN ${ }^{-}$enters the body through dietary uptake or can also be synthesized from cyanide by sulfurtransferase enzymes (Chandler and Day, 2012). Thiocyanate is eliminated in the kidneys and has a half-life of approximately 3 days (Chandler and Day, 2012). $\mathrm{SCN}^{-}$is transported into the airways after it is first incorporated from the basal side through the $\mathrm{Na}^{+} / \mathrm{I}^{-}$symporter into the airway epithelium. It is then transported into the airway lumen through anion transporters including the Cystic fibrosis transmembrane conductance regulator (CFTR) and pendrin/SLC26A4 (Suzuki et al., 2016). Both, LPO and SCN have been shown to be present in the airway surface liquid 
in large quantities (Conner et al., 2002, 2007). Once transported into the ASL, $\mathrm{SCN}^{-}$is ready to be oxidized into the antimicrobial compound hypothiocyanite by LPO, provided $\mathrm{H}_{2} \mathrm{O}_{2}$ is present (Moskwa et al., 2007).

Due to $\mathrm{SCN}^{-}$being transported by the CFTR and its role in antimicrobial defense, it was believed that cystic fibrosis patients have trouble clearing bacteria due to lack of SCN ${ }^{-}$mediated microbial killing (Moskwa et al., 2007). However, it was determined that levels of $\mathrm{SCN}^{-}$were not statistically different between $\mathrm{CF}$ and non-CF patients meaning that there could be a backup transport mechanism functioning in CF (Lorentzen et al., 2011). Additionally, it was shown that higher levels of $\mathrm{SCN}^{-}$in the airways correlated with better lung function in CF patients leading to the hypothesis that $\mathrm{SCN}^{-}$has a beneficial role (Lorentzen et al., 2011). Since animal cells do not synthesize it, increased levels of SCN come from the dietary uptake of cruciferous vegetables such as broccoli and cabbage (Lorentzen et al., 2011). During bacterial challenge in the respiratory tract neutrophils produce hypochlorous acid ( $\mathrm{HOCl}$ ) which is more toxic to host cells than $\mathrm{OSCN}^{-}$(Lorentzen et al., 2011). SCN ${ }^{-}$helps alleviate the overabundance of $\mathrm{HOCl}$ because it outcompetes $\mathrm{Cl}$ - for Myeloperoxidase (MPO) and $\mathrm{H}_{2} \mathrm{O}_{2}$, and it also reacts with $\mathrm{HOCl}$ directly which leads to the production of more $\mathrm{OSCN}^{-}$ (Lorentzen et al., 2011).

\section{Antibacterial effects of the DUOX/ $\mathrm{H}_{2} \mathrm{O}_{2} / \mathrm{LPO}$ system}

Antimicrobial effects of the DUOX/ $\mathrm{H}_{2} \mathrm{O}_{2} / \mathrm{LPO}$ system have been best demonstrated in bacteria. Table 1 lists all publications reporting microbicidal or microbistatic effects of the DUOX/ $\mathrm{H}_{2} \mathrm{O}_{2} / \mathrm{LPO}$ system in a concise manner. Several bacterial species are killed in an in vitro, "cell-free" experimental system composed of LPO, $\mathrm{H}_{2} \mathrm{O}_{2}$, and $\mathrm{SCN}^{-}$. The "cell-free" characterization refers to the absence of the cellular, host source of $\mathrm{H}_{2} \mathrm{O}_{2} \cdot \mathrm{H}_{2} \mathrm{O}_{2}$ is either added in a "bolus" manner or provided as the by-product of the enzymatic reaction between glucose and glucose oxidase (Rada et al., 2008). Generating $\mathrm{H}_{2} \mathrm{O}_{2}$ in this "cell-free" system by an enzymatic reaction better models the slow but steady nature of DUOX-mediated, enzymatic $\mathrm{H}_{2} \mathrm{O}_{2}$ release in BECs than a bolus-like addition of $\mathrm{H}_{2} \mathrm{O}_{2}$ (Rada et al., 2008; Rada and Leto, 2010). The "cell-free" model is relatively simple allowing a detailed and easy characterization of LPO-mediated killing of any microorganism including bacteria.

Numerous studies compared LPO substrate preference for microbial killing. The sensitivity of Actinobacillus actinomycetemcomitans, a bacterium important in early onset and progressive periodontitis, to LPO-mediated killing is moderate when $\mathrm{SCN}^{-}$is the substrate, but is enhanced significantly when I is provided as alternative substrate in the cellfree system (Ihalin et al., 1998, 2003). In vitro growth of Bacillus cereus, an oral periodontopathic bacterium, is also inhibited by LPO in an OSCN ${ }^{-}$concentration-dependent manner (Tenovuo et al., 1985). Unlike in the case of $A$. actinomycetemcomitans, the antimicrobial efficiency of LPO against $B$. cereus was greater with $\mathrm{SCN}^{-}$as a substrate than with I' (LPO did not oxidize $\mathrm{Cl}^{-}$) (Tenovuo et al., 1985). MPO also killed $B$. cereus that was more efficient with I' as a substrate compared to $\mathrm{Cl}^{-}$and $\mathrm{SCN}^{-}$, respectively (Tenovuo et al., 1985) (Table 1). The LPO-based system is also efficient against a variety of anaerobic bacteria in vitro (Courtois et al., 1992). Salmonella enteritidis present in different foods and fruit juices was shown to be killed by LPO purified from skim milk and supplemented with $\mathrm{SCN}^{-}$as substrate (Touch et al., 2004).

LPO is bactericidal or bacteriostatic against a wide variety of Streptococcus species. The in vitro growth and metabolism of oral streptococci, Streptococcus mutans and S. sobrinus, are much more effectively inhibited by the $\mathrm{H}_{2} \mathrm{O}_{2} / \mathrm{LPO} /$ SCN ${ }^{-}$system than $\mathrm{H}_{2} \mathrm{O}_{2}$ alone (Thomas et al., 1994). An only bacteriostatic effect of the LPO-based in vitro system against Streptococcus lactis was described and compared to its bactericidal effect against Escherichia coli (Marshall and Reiter, 1980). Studies investigating the bactericidal effect of the $\mathrm{H}_{2} \mathrm{O}_{2} /$ $\mathrm{LPO} / \mathrm{SCN}^{-}$system on Streptococcus agalactiae indicated LPO/ $\mathrm{H}_{2} \mathrm{O}_{2}$-catalyzed incorporation of $\mathrm{SCN}^{-}$into bacterial proteins and removal of reactive protein sulfhydryls from a functional role in membrane transport and glucolysis as the likely causes of the antibacterial effect of LPO (Mickelson, 1979; Mickelson and Anderson, 1984). The study by Ashby et al. (2009) described that the antimicrobial action of LPO changes the species distribution of Streptococcus co-cultures, a finding that can have in vivo relevance in the oral cavity.

The LPO-based system is also an efficient in vitro killer of E. coli, Pseudomonas fluorescens, Aeromonas hydrophila, Citrobacter freundi, Klebsiella pneumonia, Proteus mirablis, Salmonella enteritidis, Salmonella schottmuelleri, Serratia marcescens, Shigella dysenteriae, Shigella sonnei, Staphylococcus aureus, Staphylococcus citreus, and Vibrio cholerae (Bjorck et al., 1975; Tenovuo and Knuuttila, 1977a, 1977b; Mickelson, 1979; Stephens et al., 1979; Benoy et al., 2000; Bosch et al., 2000) (Table 1). Addition of LPO and SCN ${ }^{-}$to milk significantly reduces the burden of psychotrophic bacteria and increases the milk's storage time (Tenovuo and Knuuttila, 1977a). Interestingly, not only bacterial cells, but their secreted toxins can also be attacked by the $\mathrm{LPO} / \mathrm{H}_{2} \mathrm{O}_{2} /$ $\mathrm{SCN}^{-}$system. We have previously shown that the redox-active $P$. aeruginosa exotoxin pyocyanin is degraded and detoxified by LPO using DUOX1-derived $\mathrm{H}_{2} \mathrm{O}_{2}$ on airway epithelial cells (Rada et al., 2008). LPO-mediated pyocyanin inactivation is LPO and $\mathrm{H}_{2} \mathrm{O}_{2}$ concentration-dependent (Rada et al., 2008). These results indicate a complex redox interplay between the host epithelium and $P$. aeruginosa in the airways (Rada et al., 2008; Rada and Leto, 2009). All these reports support that the $\mathrm{H}_{2} \mathrm{O}_{2} / \mathrm{LPO} / \mathrm{SCN}^{-}$system is efficient against a wide variety of bacterial species in vitro and likely serves as a general, non-specific innate immune mechanism in vivo (Fig. 1).

Airway epithelial cells express DUOX1 and DUOX2 proteins in their apical plasma membrane that are the major $\mathrm{H}_{2} \mathrm{O}_{2}$ sources for the $\mathrm{H}_{2} \mathrm{O}_{2} / \mathrm{LPO} / \mathrm{SCN}^{-}$antimicrobial system (Geiszt et al., 2003; Rada, 2017). Air-liquid cultures of differentiated tracheobronbchial epithelial cells provide an excellent, cell-based, in vitro model to study the DUOX/ $\mathrm{H}_{2} \mathrm{O}_{2} /$

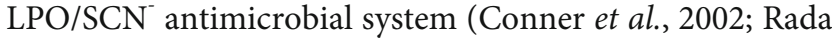
et al., 2008). We and others showed that OSCN ${ }^{-}$kills several respiratory pathogens including Burkholderia cepacia, Staphylococcus aureus, Pseudomonas aeruginosa, and Haemophilus influenzae on the surface of air-liquid cultures of differentiated primary tracheobronchial epithelial cell cultures 
or in human tracheal secretions (Wijkstrom-Frei et al., 2003; Conner et al., 2007; Moskwa et al., 2007; Rada and Leto, 2008, 2010; Gattas et al., 2009). These measurements show that DUOX-generated $\mathrm{H}_{2} \mathrm{O}_{2}$ is sufficient to fuel this antimicrobial system in airway cells. We have previously shown that $P$. aeruginosa stimulates DUOX1 activity and $\mathrm{H}_{2} \mathrm{O}_{2}$ production in airway epithelial cell lines (Rada and Leto, 2010). ALX-109 (an investigational drug consisting of lactoferrin and $\mathrm{OSCN}^{-}$) reduced in vitro P. aeruginosa $\mathrm{PAO} 1$ biofilm formation (Moreau-Marquis et al., 2015). This drug also increased the ability of tobramycin and aztreonam to inhibit biofilm formation and to reduce established PAO1 biofilms on cystic fibrosis airway epithelial cells (Moreau-Marquis et al., 2015). During Listeria monocytogenes infection, DUOX2 interacts and co-localizes with Nucleotide binding oligomerization domain 2 (NOD2) at the plasma membrane and mediates antimicrobial response to prevent cytoinvasion (Lipinski et al., 2009). This study not only demonstrated that DUOX2-derived hydrogen peroxide resulted in direct bactericidal activity, but it also amplified NF- $\kappa \mathrm{B}$ signaling in HEK293 cells cultured with the pathogenic bacterium Listeria monocytogenes (Lipinski et al., 2009). Another study found that DUOX1 activation is a general response to diverse bacterial triggers (including Salmonella typhymurium and Escherchia coli) that activate TLRs (Boots et al., 2009).

In vivo studies using non-mammalian animal models also established relevant roles for DUOX proteins in immune defenses. C. elegans expresses DUOX1 that generates ROS to trigger protective SKN1 activity via p38 MAPK signaling (Hoeven et al., 2011) suggesting that C. elegans DUOX (CreDUOX) is required for pathogen-induced ROS production as a protective immune mechanisms (Hoeven et al., 2011). Using reverse-phase high-performance chromatography and a rhodamine-based sensor for the detection of DUOX-dependent ROS, uracil-induced DUOX activation of Drosophila gut innate immunity was shown to be an important mechanism for E. carotovora clearance in flies' gut (Chen et al., 2011). Following this interesting discovery, the whole transcriptome profiles of Drosophila midgut cells following uracil stimulation revealed the identification of protein kinase genes upregulated by the treatment (Lee et al., 2015a, 2015b) and a clear implication of the Hedgehog $(\mathrm{Hh})$ signaling pathway, initially involved in early embryogenesis, and required for the full activation of DUOX (Lee et al., 2015a, 2015b). An interesting study has shown that intestinal DUOX and an associated peroxidase generates a dityrosine network in Ixodes scapularis ticks that protects the insects against infection by Borrelia burgdorferi, the causative agent of Lyme's disease (Yang et al., 2014).

In spite of all the previously introduced reports, literature addressing the in vivo antimicrobial role of the LPO-based system in mammalian hosts is largely missing. In vivo inhibition of airway LPO in sheep leads to significant decrease in bacterial clearance suggesting that LPO plays an important immune role during Pasteurella haemolytica infection (Gerson et al., 2000). In summary, the LPO-based oxidative mechanism is likely a major pillar of the first line of antibacterial immune defense in several organs including the airways, oral cavity, eyes and mammary glands.

\section{Antiviral effects of the DUOX $/ \mathrm{H}_{2} \mathrm{O}_{2} / \mathrm{LPO}$ system}

The virucidal effects of $\mathrm{H}_{2} \mathrm{O}_{2} / \mathrm{LPO} / \mathrm{SCN}^{-}$system have been demonstrated in HIV, Herpes Simplex Virus type 1 (HSV1), Respiratory Syncytial Virus (RSV), adenoviruses, echovirus, and influenza A virus (IAV) (Table 1). Treatment of HIV viruses with LPO-generated $\mathrm{OSCN}^{-}$decreased subsequent viral proliferation in lymphocytes as followed by ELISA specific to the p24 viral capsid protein (Pourtois et al., 1990). $\mathrm{H}_{2} \mathrm{O}_{2}$ was produced by the glucose/glucose oxidase system (Pourtois et al., 1990). HSV1 is an enveloped DNA virus that is ubiquitous, neurotropic, and the most common pathogenic cause of sporadic acute encephalitis in humans (Whitley, 2006; Steiner, 2011). The virus has the ability to establish and maintain a lifelong infection in neurons with frequent asymptomatic reactivation episode (Tsalenchuck et al., 2014). It is well known that infectious HSV is shed to whole saliva from time to time even during asymptomatic infection (Wittek et al., 1984). The saliva contains several components that have the ability to neutralize the virus in vitro (Mikola et al., 1995). The inhibitory effect of OSCN ${ }^{-}$against HSV1 was demonstrated but no significant inhibition of the virus was noticed when any of the components (thiocyanate or ROS) were omitted, neither did ROS alone have any inhibitory effect. The complete peroxidase system without any virus did not stress fibroblasts as observed by light microscopy suggesting that $\mathrm{OSCN}^{-}$does not have any cytotoxic effect on the cells and is indeed the antiviral agent (Mikola et al., 1995). Recently, a comparative analysis of the antiviral activity of camel, bovine, and human LPO against HSV1 revealed that all three proteins were able to inhibit HSV1 in the Vero cell model but the highest anti-HSV1 activity was exhibited by bovine LPO that inhibited HSV1 particles at a concentration of $0.5 \mu \mathrm{g} / \mu \mathrm{l}$ with the relative activity of $100 \%$ (El-Fakharany et al., 2017).

In vivo DUOX2 silencing in mouse nasal mucosa aggravated influenza virus A infection (Kim et al., 2015). Using rat airway epithelial cells, we demonstrated that both DUOX isoforms are expressed by epithelial cells and influenza $\mathrm{A}$ viruses are inactivated by epithelial cells via $\mathrm{DUOX} / \mathrm{LPO} / \mathrm{SCN}^{-}$-dependent mechanism suggesting that the DUOX system is potent at inactivating H1N2 influenza viruses prior to infection of the epithelium (Gingerich et al., 2016). DUOX1 and DUOX2 mRNA levels are also significantly increased in nasal epithelium following influenza A infection (Kim et al., 2013). Intracellular ROS generation at $1 \mathrm{~h}$ after IAV infection was significantly attenuated in normal human epithelial cells transfected with DUOX2 shRNA. Influenza virus titers from DUOX2-transfected and IAV-infected cells were significantly higher than cells transfected with control shRNA and NP expression by western blot showed a more considerable increase in DUOX2 knockdown than in control cells. These data show that $D U O X$ enzymes represent a dominant source of ROS in response to IAV infection (Kim et al., 2015).

Respiratory Syncytial Virus (RSV) is a major cause of acute lower respiratory infection in infants and young children. RSV is a leading cause of bronchiolitis worldwide (Welliver et al., 2010; Collins and Melero, 2011). During RSV infection, airway epithelial host defenses are important components for the inactivation and complete removal of the virus from the respiratory tract. The DUOX-mediated generation 
of $\mathrm{OSCN}^{-}$exhibits conflicting anti-RSV activity (Mikola et al., 1995; Fischer et al., 2011) but iodide supplementation has been shown to protect newborn lambs (McGovern et al., 2016). Because the DUOX/LPO/halide system can generate hypoiodous acid $\left(\mathrm{OI}^{-}\right)$when the iodide concentration is elevated in the airway, a lamb model of RSV was used to test if potassium iodide could enhance the LPO/halide system in vivo (McGovern et al., 2016). Newborn lambs were treated with intragastric gavage of potassium iodide that led to a 10fold increase in iodide concentration in the airway surface liquid (McGovern et al., 2016). Additionally, expiratory effort, gross lung lesions, and pulmonary expression of an RSV antigen were reduced in the potassium iodide-treated lambs compared to untreated control lambs. The authors concluded that high dose of potassium iodide supplementation can be used in vivo to lessen the severity of RSV infections by manipulating the LPO-based system (Derscheid et al., 2014). However, LPO-dependent production of $\mathrm{OSCN}^{-}$did not inactivate adenovirus or RSV but substitution of the LPO substrate $\mathrm{SCN}^{-}$with iodide (I-) resulted in a marked reduction of both adenovirus transduction and RSV titer suggesting that the $\mathrm{LPO} / \mathrm{I}^{-} / \mathrm{H}_{2} \mathrm{O}_{2}$ system can contribute to airway antiviral defense (Fischer et al., 2011). However, a treatment in vivo with an excess of iodide can induce the blockade of thyroid hormone synthesis (hypothyroidism).

Sendai virus $(\mathrm{SeV})$, also named murine parainfluenza virus type 1 belongs to the genus Respirovirus of the Paramyxoviridae family. This family is a group of enveloped non-segmented negative strand RNA viruses and include major human and animal pathogens like Newcastle disease virus, parainfluenza viruses, respiratory syncytial viruses, and the bioterrorism threat Nipah Virus. SeV causes a typical respiratory infection and has often been used as a model for respiratory virus infection (Simmons et al., 2002). Using RTPCR, Fink et al. (2008) have shown that $\mathrm{SeV}$ infection of the A549 alveolar epithelial cell line induced DUOX2 mRNA expression. Following this first report, a detailed characterization of DUOX2 mRNA and DUOX2 protein expression upon $\mathrm{SeV}$ infection was performed in different cell line models of alveolar epithelial cells and non-transformed primary normal human bronchial epithelial cells (NHBEs) (Fink et al., 2013). The authors of this study showed first that SeVinduced DUOX2/DUOAX2 expression results from autocrine/paracrine mechanism, second, IFN- $\beta$ and TNF- $\alpha$ synergize to induce DUOX2 and DUOAX2 expression, third, DUOX2 is essential for airway epithelial cells to mount an antiviral defense, and RSV interferes with the expression of DUOX2 (Fink et al., 2013). Although no direct evidence was provided in this study for the virucidal action of DUOX against $\mathrm{SeV}$, this study showed that airway epithelial cells respond with DUOX up-regulation to viral challenge.

Overall, although the $\mathrm{LPO} / \mathrm{H}_{2} \mathrm{O}_{2} / \mathrm{SCN}^{-}$system has been studied much less for its antiviral activities, accumulating observations indicate its potential to fight viral pathogens, as well. For additional information of the role of NOX/DUOX enzymes expressed in epithelial cells along the respiratory tract in the host defense against respiratory viruses, a review by Grandvaux has revisited our current knowledge (Grandvaux et al., 2015).

\section{Antifungal effects of the DUOX/ $\mathrm{H}_{2} \mathrm{O}_{2} / \mathrm{LPO}$ system}

Few reports also indicate that the LPO-based system represents an efficient antifungal mechanism. Benoy et al. tested the antifungal effect of LPO purified from goat milk in presence of physiological levels of $\mathrm{SCN}^{-}$(around $400 \mu \mathrm{M}$ ) against several fungal species, and found most of them to be sensitive to LPO-mediated killing: Aspergillus niger, Pencillium chrysogeum, Aspergillus flaws, Alternaria sp., Trichoderma sp., Corynespora cassiicola, Phytopthora meadii, Claviceps sp., and Corticium salmonicolor (Benoy et al., 2000). Mean inhibitory concentrations of LPO antifungal activities were in the range of $62-490 \mu \mathrm{g} / \mathrm{ml} \mathrm{LPO}$ (Benoy et al., 2000). Only two species tested, Candida albicans and Pythium sp., turned out to be resistant to LPO-mediated damage (Benoy et al., 2000). Other studies, however, reported the opposite, killing of C. albicans by LPO (Lenander-Lumikari, 1992; Bosch et al., 2000; Ahariz and Courtois, 2010; Kho et al., 2012). The higher sensitivity of C. albicans to $\mathrm{I}^{-}$than to $\mathrm{SCN}^{-}$as LPO substrates could partially explain these contradictory results (Majerus and Courtois, 1992; Ahariz and Courtois, 2010). Yeast and filamentous forms of Rhodutorula rubra, Saccharomyces cerevisiae, Mucor rouxii, Aspergillus niger, and Byssochlamys fulva were also exposed to the $\mathrm{H}_{2} \mathrm{O}_{2} / \mathrm{LPO} / \mathrm{SCN}$ system in buffer and apple juice and found to be damaged (Popper and Knorr, 1997). Not only bacterial but fungal toxins can also be inactivated by LPO. Different types of aflatoxin (B1, B2A, G1) were efficiently degraded in vitro by the $\mathrm{LPO} / \mathrm{H}_{2} \mathrm{O}_{2}$ system, although the enzyme substrate was not specified (Doyle and Marth, 1978). Oxidation of alpha-amanitin, a potent hepatotoxin produced by the Amanita phalloides fungus, has also been observed in vitro by the LPO/ $\mathrm{H}_{2} \mathrm{O}_{2} / \mathrm{I}^{-}$system (Morris et al., 1979; Zheleva et al., 2000).

\section{Antiparasitic effects of the DUOX/ $\mathrm{H}_{2} \mathrm{O}_{2} / \mathrm{LPO}$ system}

Sporadic observations reported that LPO also has parasiticidal activities. While tachyzoite stage Toxoplasma gondii, an obligatory intracellular parasite, is resistant to $\mathrm{H}_{2} \mathrm{O}_{2}$ in vitro, addition of LPO and I' resulted in enhanced sensitivity of the protozoan (Tanaka et al., 2006). LPO-treated T. gondii tachyzoites did not penetrate mouse fibroblasts and could also be killed intracellularly in mouse macrophages (Tanaka et al., 2006). These results suggest that the LPO-based system could inhibit the development of Toxoplasmosis after eating raw meat (Tanaka et al., 2006).

During malaria infection of the mosquito vector Anopheles gambiae, DUOX forms a dityrosine network with Immunomodulatory Peroxidase (IMPer) and decreases mosquito gut permeability to immune elicitors (Kumar et al., 2010). This network protects the microbiota by preventing activation of epithelial immunity (Kumar et al., 2010). The authors of this study showed that this mechanism provides a permissive environment for the malaria parasite development in the mosquito as it prevents activation of antimalarial response mediated nitric oxide synthase (NOS) (Kumar et al., 2010). Interestingly, when DUOX is silenced, mosquitos mount strong pathogen-specific responses to bacteria and malaria parasites. The authors found that the Oxidation Resistance 1 gene (OXR1) decreases the survival of female mosquitos to an oral challenge with ROS. OXR1 silencing also decreases 
the number of Plasmodium berghei ookinetes that survive and become oocyts suggesting that malaria parasites in mosquitoes are less susceptible to ROS damage (Kumar et al., 2010). However, susceptibility of Plasmodium falciparum, the deadliest human malaria parasite, to a peroxidase-mediated oxygen-dependent microbicidal system has been demonstrated (Malhotra et al., 1988). The in vitro study showed that the killing of malaria parasites by $\mathrm{H}_{2} \mathrm{O}_{2}, \mathrm{LPO}$, and $\mathrm{SCN}^{-}$was not due to red blood cell damage as indicated by the examination of controls after exposure to the different components. Detailed in vitro and in vivo studies of the role of the DUOX system in malaria are warranted despite the opposite effects of ROS on malaria parasite inside the mosquito gut vector and the host red blood cells. Thus, targets of LPO are not only bacteria and viruses but also include fungal and protozoan pathogens making this innate immune mechanism one of the most general ones in terms of microbial targets.

\section{Concluding remarks}

Although data collected in this review prove that the DUOX/ $\mathrm{H}_{2} \mathrm{O}_{2} / \mathrm{LPO} / \mathrm{SCN}^{-}$system is a potent, broad spectrum, antimicrobial mechanism, most of these studies were conducted in lower organisms or in in vitro cell culture systems. Surprisingly, very few studies addressed the antimicrobial role of this mechanism in mammalian organisms. Such investigations are essential to prove its physiological relevance in the most developed life forms including humans. Table 2 enlists main questions to be addressed on the field in the future.

While negative effects of DUOX1 lung function have already been described (Habibovic et al., 2016), studies are still awaited to show its beneficial role in respiratory or other infections. DUOX1 is expressed in the mouse respiratory tract and cultured murine tracheal epithelial cells suggesting that mice could serve as a great model the study the in vivo mechanistic role of DUOX1 in airway infections (Chang et al., 2013; Habibovic et al., 2016). DUOX1-deficient mice are available and provide and ideal tool to address this question (Donko et al., 2010; Rada et al., 2014b; Habibovic et al., 2016) (Table 2). Down-regulation of DUOX1 gene expression in murine airways using instilled siRNA cocktails presents another possible approach (Habibovic et al., 2016). Developing DUOX1-deficient models of larger animals would also provide a feasible option (rat, ferret, pig).

It is important to separate the potential in vivo antimicrobial roles of DUOX1 and DUOX2 from each other. Mice

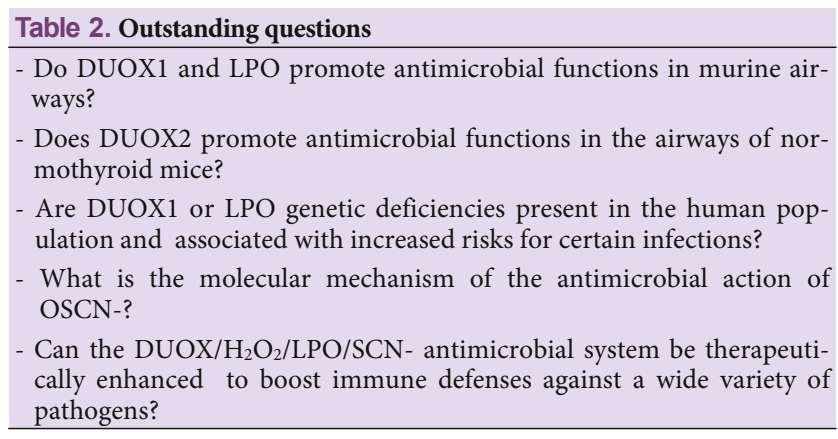

that are deficient in both, DUOX1 and DUOX2 (or their corresponding Duox activators) do not represent optimal experimental tools since roles of DUOX1 and DUOX2 cannot be distinguished from each other in these models. Although similar in structure, DUOX1 and DUOX2 are two independent genes with fairly different regulatory mechanisms discovered so far. The main in vivo role of DUOX2 is the production of thyroid hormones since DUOX2 deficiency leads to hypothyroidism in both, mice and humans. Interestingly, no study ever reported any problems of DUOX2deficient mice or human patients with infections. Although not impossible but the lack of these reports makes it unlikely that DUOX2 has a significant in vivo immune role. Infection studies performed on mice with global DUOX2 deficiency should be viewed critically since a direct immune role of DUOX2 is very hard to separate from an indirect role via dysfunction in thyroid hormone production. Even if attempts have been made to reintroduce thyroid hormones regularly to DUOX2-deficient mice from early on to circumvent this problem, it is very difficult to ensure that thyroid hormone-fed mice are normothyroid and not hypoor hyperthyroid. An ideal experimental tool to study the extrathyroid role of DUOX2 in infections would be mice with conditional DUOX2 deficiency only in target cells. There is an urgent need to develop such a mouse model (Table 2).

Similarly, to the case of DUOX1, studies focusing on the in vivo antimicrobial role of LPO in mammalian experimental models are also lacking. Although the use of the LPO inhibitor dapsone delivered the most such in vivo results until now, more specific experimental tools are required to address LPO. There are no LPO-deficient murine or other mammalian models available to investigate this highly relevant question. In fact, LPO expression has not even been investigated in murine airways so far. Our results presented in Fig. 2 show that LPO is highly expressed in the mouse trachea and, similarly to humans and other mammals studied, it shows a submucosal tissue distribution. Thus, mouse airways express both DUOX and LPO and provide therefore a useful animal model to address the in vivo role of this antimicrobial system in infectious diseases.

The field also suffers from lack of antibodies that reliably and specifically recognize only one DUOX isoform. Availability of such research tools would accelerate studies focusing on distinguishing the roles of DUOX1 and DUOX2 in in vivo models.

The vast amount of literature cited here shows that the DUOX $/ \mathrm{H}_{2} \mathrm{O}_{2} / \mathrm{LPO} / \mathrm{SCN}^{-}$antimicrobial system provides a fast-reacting, powerful, innate immune mechanism for host epithelia to fight several pathogens in a non-specific fashion. A detailed understanding of its mechanism of action is, however, still unclear. How can this oxidative mechanism generating mildly reactive ROS efficiently attack a wide variety of microorganisms? The primary molecular targets of $\mathrm{OSCN}^{-}$ in microbes are likely proteins with SH moiety (Bafort et al., 2014). Altering the function of several such proteins could interfere with general (glycolysis, respiration, nutrient transport) or microbe-specific mechanisms resulting in damage and killing of the targeted microorganisms (Bafort et al., 2014). The exact molecular mechanism of the antimicrobial action of $\mathrm{OSCN}^{-}$remains, however, to be investigated in the 
future.

On the practical side, the large amounts of published results collected here provide a strong basis and enough enthusiasm for the potential therapeutic targeting of the LPO-based system to fight infections. Since delivering a detailed overview about this topic is beyond the scope of this review, we only mention a few key points to be considered. Increasing the concentration of any one or more components of the LPObased system would theoretically lead to a larger $\mathrm{OSCN}^{-}$yield and stronger microbicidal activity. Administration of $\mathrm{SCN}^{-}$ or LPO (or both) is more likely a safer approach as enhancing DUOX1 activity in the airways could lead to unwanted allergic side effects (Chang et al., 2013; Rada et al., 2014a; Habibovic et al., 2016). While oral administration is more convenient and could provide more stable airway levels of $\mathrm{SCN}^{-}$and LPO over time, it has to pass the stomach, get absorbed in the blood and accumulated in the airway surface liquid. On the other hand, nebulized administration delivers $\mathrm{SCN}^{-}$or LPO directly to its target location, it would, however, have to be repeated regularly as their concentrations are expected to drop rapidly.

While several challenges still lie ahead to have a complete understanding and characterization of the DUOX/LPO-based antimicrobial defense system, it provides a unique, potent, broad spectrum, microbicidal mechanism of interest to both basic and applied research.

\section{Acknowledgements}

The authors thank Elizabeth Sisk for creating the scientific illustration shown in Fig. 1 and Dr. Tamás Nagy, small animal pathologist and associate professor at the Department of Pathology at the University of Georgia, for help with preparation of Fig. 2. The authors are also thankful to the University of Georgia Veterinary Diagnostic Laboratories for help with tissue sample preparation.

\section{References}

Ahariz, M. and Courtois, P. 2010. Candida albicans susceptibility to lactoperoxidase-generated hypoiodite. Clin. Cosmet. Investig. Dent. 2, 69-78.

Allen, P.Z. and Morrison, M. 1966. Lactoperoxidase. Vi. Immunochemical studies on lactoperoxidase from the milk of several species. Arch. Biochem. Biophys. 113, 540-547.

Ameziane-El-Hassani, R., Morand, S., Boucher, J.L., Frapart, Y.M., Apostolou, D., Agnandji, D., Gnidehou, S., Ohayon, R., NoelHudson, M.S., Francon, J., et al. 2005. Dual oxidase-2 has an intrinsic $\mathrm{Ca}^{2+}$-dependent $\mathrm{H}_{2} \mathrm{O}_{2}$-generating activity. J. Biol. Chem. 280, 30046-30054.

Asehnoune, K., Strassheim, D., Mitra, S., Kim, J.Y., and Abraham, E. 2004. Involvement of reactive oxygen species in toll-like receptor 4-dependent activation of NF- $\mathrm{kB}$. J. Immunol. 172, 25222529.

Ashby, M.T., Kreth, J., Soundarajan, M., and Sivuilu, L.S. 2009. Influence of a model human defensive peroxidase system on oral streptococcal antagonism. Microbiology 155, 3691-3700.

Bafort, F., Parisi, O., Perraudin, J.P., and Jijakli, M.H. 2014. Mode of action of lactoperoxidase as related to its antimicrobial activity: A review. Enzyme Res. 2014, 517164.
Bedard, K. and Krause, K.H. 2007. The NOX family of ROS-generating NADPH oxidases: Physiology and pathophysiology. Physiol. Rev. 87, 245-313.

Bedard, K., Lardy, B., and Krause, K.H. 2007. NOX family NADPH oxidases: not just in mammals. Biochimie 89, 1107-1112.

Benoy, M.J., Essy, A.K., Sreekumar, B., and Haridas, M. 2000. Thiocyanate mediated antifungal and antibacterial property of goat milk lactoperoxidase. Life Sci. 66, 2433-2439.

Bjorck, L., Rosen, C., Marshall, V., and Reiter, B. 1975. Antibacterial activity of the lactoperoxidase system in milk against pseudomonads and other Gram-negative bacteria. Appl. Microbiol. 30, 199-204.

Bjorkman, U. and Ekholm, R. 1984. Generation of $\mathrm{H}_{2} \mathrm{O}_{2}$ in isolated porcine thyroid follicles. Endocrinology 115, 392-398.

Bokoch, G.M. and Knaus, U.G. 2003. NADPH oxidases: Not just for leukocytes anymore! Trends Biochem. Sci. 28, 502-508.

Boots, A.W., Hristova, M., Kasahara, D.I., Haenen, G.R., Bast, A., and van der Vliet, A. 2009. ATP-mediated activation of the NADPH oxidase DUOX1 mediates airway epithelial responses to bacterial stimuli. J. Biol. Chem. 284, 17858-17867.

Bosch, E.H., van Doorne, H., and de Vries, S. 2000. The lactoperoxidase system: The influence of iodide and the chemical and antimicrobial stability over the period of about 18 months. J. Appl. Microbiol. 89, 215-224.

Carlsson, J., Edlund, M.B., and Hanstrom, L. 1984. Bactericidal and cytotoxic effects of hypothiocyanite-hydrogen peroxide mixtures. Infect. Immun. 44, 581-586.

Carre, A., Louzada, R.A., Fortunato, R.S., Ameziane-El-Hassani, R., Morand, S., Ogryzko, V., de Carvalho, D.P., Grasberger, H., Leto, T.L., and Dupuy, C. 2015. When an intramolecular disulfide bridge governs the interaction of DUOX2 with its partner DUOXA2. Antioxid. Redox Signal. 23, 724-733.

Carvalho, D.P. and Dupuy, C. 2013. Role of the NADPH oxidases DUOX and NOX4 in thyroid oxidative stress. Eur. Thyroid J. 2, 160-167.

Cegolon, L., Salata, C., Piccoli, E., Juarez, V., Palu, G., Mastrangelo, G., and Calistri, A. 2014. In vitro antiviral activity of hypothiocyanite against $\mathrm{A} / \mathrm{H} 1 \mathrm{N1} / 2009$ pandemic influenza virus. Int. J. Hyg. Environ. Health 217, 17-22.

Chandler, J.D. and Day, B.J. 2012. Thiocyanate: A potentially useful therapeutic agent with host defense and antioxidant properties. Biochem. Pharmacol. 84, 1381-1387.

Chang, S., Linderholm, A., Franzi, L., Kenyon, N., Grasberger, H., and Harper, R. 2013. Dual oxidase regulates neutrophil recruitment in allergic airways. Free Radic. Biol. Med. 65, 38-46.

Chavez, V., Mohri-Shiomi, A., and Garsin, D.A. 2009. Ce-Duox1/ BLI-3 generates reactive oxygen species as a protective innate immune mechanism in Caenorhabditis elegans. Infect. Immun. 77, 4983-4989.

Chen, X., Lee, K.A., Ha, E.M., Lee, K.M., Seo, Y.Y., Choi, H.K., Kim, H.N., Kim, M.J., Cho, C.S., Lee, S.Y., et al. 2011. A specific and sensitive method for detection of hypochlorous acid for the imaging of microbe-induced $\mathrm{HOCl}$ production. Chem. Commun. (Camb) 47, 4373-4375.

Chen, C., Li, L., Zhou, H.J., and Min, W. 2017. The role of NOX4 and TRX2 in angiogenesis and their potential cross-talk. Antioxidants (Basel) 6, 42.

Collins, P.L. and Melero, J.A. 2011. Progress in understanding and controlling respiratory syncytial virus: Still crazy after all these years. Virus Res. 162, 80-99.

Conner, G.E., Salathe, M., and Forteza, R. 2002. Lactoperoxidase and hydrogen peroxide metabolism in the airway. Am. J. Respir. Crit. Care Med. 166, S57-S61.

Conner, G.E., Wijkstrom-Frei, C., Randell, S.H., Fernandez, V.E., and Salathe, M. 2007. The lactoperoxidase system links anion transport to host defense in cystic fibrosis. FEBS Lett. 581, 271278. 
Courtois, P., Majerus, P., Labbe, M., Vanden Abbeele, A., Yourassowsky, E., and Pourtois, M. 1992. Susceptibility of anaerobic microorganisms to hypothiocyanite produced by lactoperoxidase. Acta Stomatol. Belg. 89, 155-162.

Csillag, C., Nielsen, O.H., Vainer, B., Olsen, J., Dieckgraefe, B.K., Hendel, J., Vind, I., Dupuy, C., Nielsen, F.C., and Borup, R. 2007. Expression of the genes dualoxidase 2, lipocalin 2 and regenerating islet-derived 1 alpha in Crohn's disease. Scand. J. Gastroenterol. 42, 454-463.

Davies, M.J., Hawkins, C.L., Pattison, D.I., and Rees, M.D. 2008. Mammalian heme peroxidases: from molecular mechanisms to health implications. Antioxid. Redox Signal. 10, 1199-1234.

De Deken, X., Corvilain, B., Dumont, J.E., and Miot, F. 2014. Roles of DUOX-mediated hydrogen peroxide in metabolism, host defense, and signaling. Antioxid. Redox Signal. 20, 2776-2793.

De Deken, X., Wang, D., Many, M.C., Costagliola, S., Libert, F., Vassart, G., Dumont, J.E., and Miot, F. 2000. Cloning of two human thyroid cDNAs encoding new members of the NADPH oxidase family. J. Biol. Chem. 275, 23227-23233.

Derscheid, R.J., van Geelen, A., Berkebile, A.R., Gallup, J.M., Hostetter, S.J., Banfi, B., McCray, P.B.Jr., and Ackermann, M.R. 2014. Increased concentration of iodide in airway secretions is associated with reduced respiratory syncytial virus disease severity. Am. J. Respir. Cell Mol. Biol. 50, 389-397.

Dickinson, J.D., Sweeter, J.M., Warren, K.J., Ahmad, I.M., De Deken, X., Zimmerman, M.C., and Brody, S.L. 2018. Autophagy regulates DUOX1 localization and superoxide production in airway epithelial cells during chronic IL-13 stimulation. Redox Biol. 14, 272-284.

Donko, A., Morand, S., Korzeniowska, A., Boudreau, H.E., Zana, M., Hunyady, L., Geiszt, M., and Leto, T.L. 2014. Hypothyroidismassociated missense mutation impairs NADPH oxidase activity and intracellular trafficking of DUOX2. Free Radic. Biol. Med. 73, 190-200.

Donko, A., Peterfi, Z., Sum, A., Leto, T., and Geiszt, M. 2005. Dual oxidases. Philos. Trans. R. Soc. Lond. B Biol. Sci. 360, 2301-2308.

Donko, A., Ruisanchez, E., Orient, A., Enyedi, B., Kapui, R., Peterfi, Z., de Deken, X., Benyo, Z., and Geiszt, M. 2010. Urothelial cells produce hydrogen peroxide through the activation of DUOX1. Free Radic. Biol. Med. 49, 2040-2048.

Doyle, M.P. and Marth, E.H. 1978. Degradation of aflatoxin by lactoperoxidase. Z. Lebensm. Unters. Forsch. 166, 271-273.

Dupuy, C., Kaniewski, J., Deme, D., Pommier, J., and Virion, A. 1989. NADPH-dependent $\mathrm{H}_{2} \mathrm{O}_{2}$ generation catalyzed by thyroid plasma membranes. Studies with electron scavengers. Eur. J. Biochem. 185, 597-603.

Dupuy, C., Ohayon, R., Valent, A., Noel-Hudson, M.S., Deme, D., and Virion, A. 1999. Purification of a novel flavoprotein involved in the thyroid NADPH oxidase. Cloning of the porcine and human cDNAs. J. Biol. Chem. 274, 37265-37269.

Edens, W.A., Sharling, L., Cheng, G., Shapira, R., Kinkade, J.M., Lee, T., Edens, H.A., Tang, X., Sullards, C., Flaherty, D.B., et al. 2001. Tyrosine cross-linking of extracellular matrix is catalyzed by DUOX, a multidomain oxidase/peroxidase with homology to the phagocyte oxidase subunit gp91phox. J. Cell. Biol. 154, 879892.

El-Chemaly, S., Salathe, M., Baier, S., Conner, G.E., and Forteza, R. 2003. Hydrogen peroxide-scavenging properties of normal human airway secretions. Am. J. Respir. Crit. Care Med. 167, 425-430.

El-Fakharany, E.M., Uversky, V.N., and Redwan, E.M. 2017. Comparative analysis of the antiviral activity of camel, bovine, and human lactoperoxidases against herpes simplex virus type 1 . Appl. Biochem. Biotechnol. 182, 294-310.

El Hassani, R.A., Benfares, N., Caillou, B., Talbot, M., Sabourin, J.C., Belotte, V., Morand, S., Gnidehou, S., Agnandji, D., Ohayon, R., et al. 2005. Dual oxidase 2 is expressed all along the digestive tract. Am. J. Physiol. Gastrointest. Liver Physiol. 288, G933-G942.
Fink, K., Duval, A., Martel, A., Soucy-Faulkner, A., and Grandvaux, N. 2008. Dual role of NOX2 in respiratory syncytial virus- and sendai virus-induced activation of NF- $\mathrm{KB}$ in airway epithelial cells. J. Immunol. 180, 6911-6922.

Fink, K., Martin, L., Mukawera, E., Chartier, S., De Deken, X., Brochiero, E., Miot, F., and Grandvaux, N. 2013. IFNß/TNFa synergism induces a non-canonical STAT2/IRF9-dependent pathway triggering a novel DUOX2 NADPH oxidase-mediated airway antiviral response. Cell Res. 23, 673-690.

Fischer, A.J., Lennemann, N.J., Krishnamurthy, S., Pocza, P., Durairaj, L., Launspach, J.L., Rhein, B.A., Wohlford-Lenane, C., Lorentzen, D., Banfi, B., et al. 2011. Enhancement of respiratory mucosal antiviral defenses by the oxidation of iodide. Am. J. Respir. Cell Mol. Biol. 45, 874-881.

Fischer, H., Gonzales, L.K., Kolla, V., Schwarzer, C., Miot, F., Illek, B., and Ballard, P.L. 2007. Developmental regulation of DUOX1 expression and function in human fetal lung epithelial cells. Am. J. Physiol. Lung Cell. Mol. Physiol. 292, L1506-L1514.

Forteza, R., Salathe, M., Miot, F., Forteza, R., and Conner, G.E. 2005. Regulated hydrogen peroxide production by DUOX in human airway epithelial cells. Am. J. Respir. Cell Mol. Biol. 32, 462-469.

Fortunato, R.S., Lima de Souza, E.C., Ameziane-el Hassani, R., Boufraqech, M., Weyemi, U., Talbot, M., Lagente-Chevallier, O., de Carvalho, D.P., Bidart, J.M., Schlumberger, M., et al. 2010. Functional consequences of dual oxidase-thyroperoxidase interaction at the plasma membrane. J. Clin. Endocrinol. Metab. 95, 5403-5411.

Gattas, M.V., Forteza, R., Fragoso, M.A., Fregien, N., Salas, P., Salathe, M., and Conner, G.E. 2009. Oxidative epithelial host defense is regulated by infectious and inflammatory stimuli. Free Radic. Biol. Med. 47, 1450-1458.

Geiszt, M. and Leto, T.L. 2004. The Nox family of NAD(P)H oxidases: Host defense and beyond. J. Biol. Chem. 279, 51715-51718.

Geiszt, M., Witta, J., Baffi, J., Lekstrom, K., and Leto, T.L. 2003. Dual oxidases represent novel hydrogen peroxide sources supporting mucosal surface host defense. FASEB J. 17, 1502-1504.

Genestra, M. 2007. Oxyl radicals, redox-sensitive signalling cascades and antioxidants. Cell Signal. 19, 1807-1819.

Gerson, C., Sabater, J., Scuri, M., Torbati, A., Coffey, R., Abraham, J.W., Lauredo, I., Forteza, R., Wanner, A., Salathe, M., et al. 2000. The lactoperoxidase system functions in bacterial clearance of airways. Am. J. Respir. Cell Mol. Biol. 22, 665-671.

Gingerich, A., Pang, L., Hanson, J., Dlugolenski, D., Streich, R., Lafontaine, E.R., Nagy, T., Tripp, R.A., and Rada, B. 2016. Hypothiocyanite produced by human and rat respiratory epithelial cells inactivates extracellular H1N2 influenza A virus. Inflamm. Res. $65,71-80$.

Goldman, A.S. and Smith, C.W. 1973. Host resistance factors in human milk. J. Pediatr. 82, 1082-1090.

Grandvaux, N., Mariani, M., and Fink, K. 2015. Lung epithelial NOX/ DUOX and respiratory virus infections. Clin. Sci. (Lond) 128, 337-347.

Grasberger, H. 2010. Defects of thyroidal hydrogen peroxide generation in congenital hypothyroidism. Mol. Cell. Endocrinol. 322, 99-106.

Grasberger, H., De Deken, X., Mayo, O.B., Raad, H., Weiss, M., Liao, X.H., and Refetoff, S. 2012. Mice deficient in dual oxidase maturation factors are severely hypothyroid. Mol. Endocrinol. 26, 481-492.

Grasberger, H., De Deken, X., Miot, F., Pohlenz, J., and Refetoff, S. 2007. Missense mutations of dual oxidase 2 (DUOX2) implicated in congenital hypothyroidism have impaired trafficking in cells reconstituted with DUOX2 maturation factor. Mol. Endocrinol. 21, 1408-1421.

Grasberger, H. and Refetoff, S. 2006. Identification of the maturation factor for dual oxidase. Evolution of an eukaryotic operon equivalent. J. Biol. Chem. 281, 18269-18272. 
Grieve, P.A., Dionysius, D.A., and Vos, A.C. 1992. In vitro antibacterial activity of the lactoperoxidase system towards enterotoxigenic strains of Escherichia coli. Zentralbl. Veterinarmed. B. 39, 537-545.

Ha, E.M., Lee, K.A., Park, S.H., Kim, S.H., Nam, H.J., Lee, H.Y., Kang, D., and Lee, W.J. 2009a. Regulation of DUOX by the Gaq-phospholipase $\mathrm{C} \beta-\mathrm{Ca}^{2+}$ pathway in Drosophila gut immunity. Dev. Cell. 16, 386-397.

Ha, E.M., Lee, K.A., Seo, Y.Y., Kim, S.H., Lim, J.H., Oh, B.H., Kim, J., and Lee, W.J. 2009b. Coordination of multiple dual oxidaseregulatory pathways in responses to commensal and infectious microbes in Drosophila gut. Nat. Immunol. 10, 949-957.

Ha, E.M., Oh, C.T., Bae, Y.S., and Lee, W.J. 2005. A direct role for dual oxidase in Drosophila gut immunity. Science 310, 847-850.

Habibovic, A., Hristova, M., Heppner, D.E., Danyal, K., Ather, J.L., Janssen-Heininger, Y.M., Irvin, C.G., Poynter, M.E., Lundblad, L.K., Dixon, A.E., et al. 2016. DUOX1 mediates persistent epithelial EGFR activation, mucous cell metaplasia, and airway remodeling during allergic asthma. JCI Insight 1, e88811.

Harman, D. 1956. Aging: A theory based on free radical and radiation chemistry. J. Gerontol. 11, 298-300.

Harman, D. 1981. The aging process. Proc. Natl. Acad. Sci. USA 78 , 7124-7128.

Harper, R.W., Xu, C., Eiserich, J.P., Chen, Y., Kao, C.Y., Thai, P., Setiadi, H., and Wu, R. 2005. Differential regulation of dual NADPH oxidases/peroxidases, DUOX1 and DUOX2, by Th1 and Th2 cytokines in respiratory tract epithelium. FEBS Lett. 579, 4911-4917.

Harper, R.W., Xu, C., McManus, M., Heidersbach, A., and Eiserich, J.P. 2006. DUOX2 exhibits potent heme peroxidase activity in human respiratory tract epithelium. FEBS Lett. 580, 5150-5154.

Hoeven, R., McCallum, K.C., Cruz, M.R., and Garsin, D.A. 2011. Ce-DUOX1/BLI-3 generated reactive oxygen species trigger protective SKN-1 activity via p38 MAPK signaling during infection in C. elegans. PLoS Pathog. 7, e1002453.

Hoste, C., Dumont, J.E., Miot, F., and De Deken, X. 2012. The type of DUOX-dependent ROS production is dictated by defined sequences in DUOXA. Exp. Cell Res. 318, 2353-2364.

Ihalin, R., Loimaranta, V., Lenander-Lumikari, M., and Tenovuo, J. 1998. The effects of different (pseudo)halide substrates on peroxidase-mediated killing of Actinobacillus actinomycetemcomitans. J. Periodont. Res. 33, 421-427.

Ihalin, R., Pienihakkinen, K., Lenander, M., Tenovuo, J., and Jousimies-Somer, H. 2003. Susceptibilities of different Actinobacillus actinomycetemcomitans strains to lactoperoxidase-iodide-hydrogen peroxide combination and different antibiotics. Int. J. Antimicrob. Agents 21, 434-440.

Jha, J.C., Watson, A.M.D., Mathew, G., de Vos, L.C., and JandeleitDahm, K. 2017. The emerging role of NADPH oxidase NOX5 in vascular disease. Clin. Sci. (Lond) 131, 981-990.

Johnson, K.R., Marden, C.C., Ward-Bailey, P., Gagnon, L.H., Bronson, R.T., and Donahue, L.R. 2007. Congenital hypothyroidism, dwarfism, and hearing impairment caused by a missense mutation in the mouse dual oxidase 2 gene, DUOX2. Mol. Endocrinol. 21, 1593-1602.

Joo, J.H., Ryu, J.H., Kim, C.H., Kim, H.J., Suh, M.S., Kim, J.O., Chung, S.Y., Lee, S.N., Kim, H.M., Bae, Y.S., et al. 2012. Dual oxidase 2 is essential for the toll-like receptor 5-mediated inflammatory response in airway mucosa. Antioxid. Redox Signal. 16, 57-70.

Kawahara, T., Kuwano, Y., Teshima-Kondo, S., Takeya, R., Sumimoto, H., Kishi, K., Tsunawaki, S., Hirayama, T., and Rokutan, K. 2004. Role of nicotinamide adenine dinucleotide phosphate oxidase 1 in oxidative burst response to toll-like receptor 5 signaling in large intestinal epithelial cells. J. Immunol. 172, 30513058.

Kho, H.S., Kim, Y.Y., Chang, J.Y., Kim, M.J., and Lee, S.G. 2012. Candidacidal activities of the glucose oxidase-mediated lactoperoxidase system. Arch. Oral. Biol. 57, 684-688.
Kim, H.J., Kim, C.H., Kim, M.J., Ryu, J.H., Seong, S.Y., Kim, S., Lim, S.J., Holtzman, M.J., and Yoon, J.H. 2015. The induction of pattern-recognition receptor expression against influenza A virus through DUOX2-derived reactive oxygen species in nasal mucosa. Am. J. Respir. Cell Mol. Biol. 53, 525-535.

Kim, H.J., Kim, C.H., Ryu, J.H., Kim, M.J., Park, C.Y., Lee, J.M., Holtzman, M.J., and Yoon, J.H. 2013. Reactive oxygen species induce antiviral innate immune response through IFN- $\lambda$ regulation in human nasal epithelial cells. Am. J. Respir. Cell Mol. Biol. 49, 855-865.

Kim, J.H., Lee, J., Bae, S.J., Kim, Y., Park, B.J., Choi, J.W., Kwon, J., Cha, G.H., Yoo, H.J., Jo, E.K., et al. 2017. NADPH oxidase 4 is required for the generation of macrophage migration inhibitory factor and host defense against Toxoplasma gondii infection. Sci. Rep. 7, 6361.

Klebanoff, S.J., Clem, W.H., and Luebke, R.G. 1966. The peroxidase-thiocyanate-hydrogen peroxide antimicrobial system. Biochim. Biophys. Acta 117, 63-72.

Klebanoff, S.J. and Luebke, R.G. 1965. The antilactobacillus system of saliva. Role of salivary peroxidase. Proc. Soc. Exp. Biol. Med. 118, 483-486.

Kumar, S., Molina-Cruz, A., Gupta, L., Rodrigues, J., and BarillasMury, C. 2010. A peroxidase/dual oxidase system modulates midgut epithelial immunity in Anopheles gambiae. Science 327, 1644-1648.

Lambeth, J.D. 2004. Nox enzymes and the biology of reactive oxygen. Nat. Rev. Immunol. 4, 181-189.

Lambeth, J.D. and Neish, A.S. 2014. Nox enzymes and new thinking on reactive oxygen: A double-edged sword revisited. Annu. Rev. Pathol. 9, 119-145.

Lee, K.A., Kim, B., Bhin, J., Kim, D.H., You, H., Kim, E.K., Kim, S.H., Ryu, J.H., Hwang, D., and Lee, W.J. 2015a. Bacterial uracil modulates Drosophila DUOX-dependent gut immunity via hedgehog-induced signaling endosomes. Cell Host Microbe 17, 191-204.

Lee, K.A., Kim, B., You, H., and Lee, W.J. 2015b. Uracil-induced signaling pathways for DUOX-dependent gut immunity. Fly (Austin) 9, 115-120.

Lenander-Lumikari, M. 1992. Inhibition of Candida albicans by the peroxidase/SCN-/ $\mathrm{H}_{2} \mathrm{O}_{2}$ system. Oral. Microbiol. Immunol. 7, 315-320.

Leto, T.L., Morand, S., Hurt, D., and Ueyama, T. 2009. Targeting and regulation of reactive oxygen species generation by NOX family NADPH oxidases. Antioxid. Redox Signal. 11, 2607-2619.

Li, Y. and Pagano, P.J. 2017. Microvascular NADPH oxidase in health and disease. Free Radic. Biol. Med. 109, 33-47.

Lipinski, S., Till, A., Sina, C., Arlt, A., Grasberger, H., Schreiber, S., and Rosenstiel, P. 2009. DUOX2-derived reactive oxygen species are effectors of NOD2-mediated antibacterial responses. $J$. Cell Sci. 122, 3522-3530.

Little, A.C., Sulovari, A., Danyal, K., Heppner, D.E., Seward, D.J., and van der Vliet, A. 2017. Paradoxical roles of dual oxidases in cancer biology. Free Radic. Biol. Med. 110, 117-132.

Liu, T., Castro, S., Brasier, A.R., Jamaluddin, M., Garofalo, R.P., and Casola, A. 2004. Reactive oxygen species mediate virus-induced STAT activation: Role of tyrosine phosphatases. J. Biol. Chem. 279, 2461-2469.

Lorentzen, D., Durairaj, L., Pezzulo, A.A., Nakano, Y., Launspach, J., Stoltz, D.A., Zamba, G., McCray, P.B.Jr., Zabner, J., Welsh, M.J., et al. 2011. Concentration of the antibacterial precursor thiocyanate in cystic fibrosis airway secretions. Free Radic. Biol. Med. 50, 1144-1150.

Majerus, P.M. and Courtois, P.A. 1992. Susceptibility of Candida albicans to peroxidase-catalyzed oxidation products of thiocyanate, iodide and bromide. J. Biol. Buccale 20, 241-245.

Malhotra, K., Salmon, D., Le Bras, J., and Vilde, J.L. 1988. Susceptibility of Plasmodium falciparum to a peroxidase-mediated oxygendependent microbicidal system. Infect. Immun. 56, 3305-3309. 
Marshall, V.M. and Reiter, B. 1980. Comparison of the antibacterial activity of the hypothiocyanite anion towards Streptococcus lactis and Escherichia coli. J. Gen. Microbiol. 120, 513-516.

McGovern, F.M., Magee, D.A., Browne, J.A., MacHugh, D.E., and Boland, T.M. 2016. Iodine supplementation of the pregnant dam alters intestinal gene expression and immunoglobulin uptake in the newborn lamb. Animal 10, 598-606.

Meitzler, J.L., Hinde, S., Banfi, B., Nauseef, W.M., and Ortiz de Montellano, P.R. 2013. Conserved cysteine residues provide a protein-protein interaction surface in dual oxidase (DUOX) proteins. J. Biol. Chem. 288, 7147-7157.

Mickelson, M.N. 1979. Antibacterial action of lactoperoxidasethiocyanate-hydrogen peroxide on Streptococcus agalactiae. Appl. Environ. Microbiol. 38, 821-826.

Mickelson, M.N. and Anderson, A.J. 1984. Cystine antagonism of the antibacterial action of lactoperoxidase-thiocyanate-hydrogen peroxide on Streptococcus agalactiae. Appl. Environ. Microbiol. 47, 338-342.

Mikola, H., Waris, M., and Tenovuo, J. 1995. Inhibition of herpes simplex virus type 1 , respiratory syncytial virus and echovirus type 11 by peroxidase-generated hypothiocyanite. Antiviral Res. 26, 161-171.

Mistry, R.K. and Brewer, A.C. 2017. Redox regulation of gasotransmission in the vascular system: A focus on angiogenesis. Free Radic. Biol. Med. 108, 500-516.

Mittal, M., Siddiqui, M.R., Tran, K., Reddy, S.P., and Malik, A.B. 2014. Reactive oxygen species in inflammation and tissue injury. Antioxid Redox Signal. 20, 1126-1167.

Morand, S., Agnandji, D., Noel-Hudson, M.S., Nicolas, V., Buisson, S., Macon-Lemaitre, L., Gnidehou, S., Kaniewski, J., Ohayon, R., Virion, A., et al. 2004. Targeting of the dual oxidase $2 \mathrm{~N}$-terminal region to the plasma membrane. J. Biol. Chem. 279, 30244-30251.

Morand, S., Ueyama, T., Tsujibe, S., Saito, N., Korzeniowska, A., and Leto, T.L. 2009. DUOX maturation factors form cell surface complexes with DUOX affecting the specificity of reactive oxygen species generation. FASEB J. 23, 1205-1218.

Moreau-Marquis, S., Coutermarsh, B., and Stanton, B.A. 2015. Combination of hypothiocyanite and lactoferrin (ALX-109) enhances the ability of tobramycin and aztreonam to eliminate Pseudomonas aeruginosa biofilms growing on cystic fibrosis airway epithelial cells. J. Antimicrob. Chemother. 70, 160-166.

Moribe, H., Konakawa, R., Koga, D., Ushiki, T., Nakamura, K., and Mekada, E. 2012. Tetraspanin is required for generation of reactive oxygen species by the dual oxidase system in Caenorhabditis elegans. PLoS Genet. 8, e1002957.

Moribe, H. and Mekada, E. 2013. Co-occurrence of tetraspanin and ROS generators: Conservation in protein cross-linking and other developmental processes. Worm 2, e23415.

Morris, P.W., Kelley, K.M., and Logas, W.G. 1979. Alpha-amanitin: Inactivation by bovine lactoperoxidase. Experientia 35, 589-591.

Moskwa, P., Lorentzen, D., Excoffon, K.J., Zabner, J., McCray, P.B.Jr., Nauseef, W.M., Dupuy, C., and Banfi, B. 2007. A novel host defense system of airways is defective in cystic fibrosis. Am. J. Respir. Crit. Care Med. 175, 174-183.

Muzza, M. and Fugazzola, L. 2017. Disorders of $\mathrm{H}_{2} \mathrm{O}_{2}$ generation. Best Pract. Res. Clin. Endocrinol. Metab. 31, 225-240.

Nauseef, W.M. 2018. Biosynthesis of human myeloperoxidase. Arch. Biochem. Biophys. 642, 1-9.

Niethammer, P., Grabher, C., Look, A.T., and Mitchison, T.J. 2009. A tissue-scale gradient of hydrogen peroxide mediates rapid wound detection in zebrafish. Nature 459, 996-999.

Ohye, H. and Sugawara, M. 2010. Dual oxidase, hydrogen peroxide and thyroid diseases. Exp. Biol. Med. (Maywood) 235, 424-433.

Pachucki, J., Wang, D., Christophe, D., and Miot, F. 2004. Structural and functional characterization of the two human THOX/DUOX genes and their $5^{\prime}$-flanking regions. Mol. Cell. Endocrinol. 214, $53-62$.
Panday, A., Sahoo, M.K., Osorio, D., and Batra, S. 2015. NADPH oxidases: An overview from structure to innate immunity-associated pathologies. Cell. Mol. Immunol. 12, 5-23.

Park, H.S., Jung, H.Y., Park, E.Y., Kim, J., Lee, W.J., and Bae, Y.S. 2004. Cutting edge: Direct interaction of TLR4 with NAD(P)H oxidase 4 isozyme is essential for lipopolysaccharide-induced production of reactive oxygen species and activation of NF- $\kappa B$. $J$. Immunol. 173, 3589-3593.

Park, H.S., Park, D., and Bae, Y.S. 2006. Molecular interaction of NADPH oxidase 1 with $\beta$ Pix and NOX Organizer 1. Biochem. Biophys. Res. Commun. 339, 985-990.

Popper, L. and Knorr, D. 1997. Inactivation of yeast and filamentous fungi by the lactoperoxidase-hydrogen peroxide-thiocyanatesystem. Nahrung 41, 29-33.

Pourtois, M., Binet, C., Van Tieghem, N., Courtois, P., Vandenabbeele, A., and Thiry, L. 1990. Inhibition of HIV infectivity by lactoperoxidase-produced hypothiocyanite. J. Biol. Buccale 18, 251-253.

Prieto-Bermejo, R. and Hernandez-Hernandez, A. 2017. The importance of NADPH oxidases and redox signaling in angiogenesis. Antioxidants (Basel) 6, 32 .

Rada, B. 2017. Neutrophil extracellular trap release driven by bacterial motility: Relevance to cystic fibrosis lung disease. Commun. Integr. Biol. 10, e1296610.

Rada, B., Boudreau, H.E., Park, J.J., and Leto, T.L. 2014a. Histamine stimulates hydrogen peroxide production by bronchial epithelial cells via histamine $\mathrm{H} 1$ receptor and dual oxidase. Am. J. Respir. Cell Mol. Biol. 50, 125-134.

Rada, B., Lekstrom, K., Damian, S., Dupuy, C., and Leto, T.L. 2008. The Pseudomonas toxin pyocyanin inhibits the dual oxidase-based antimicrobial system as it imposes oxidative stress on airway epithelial cells. J. Immunol. 181, 4883-4893.

Rada, B. and Leto, T.L. 2008. Oxidative innate immune defenses by NOX/DUOX family NADPH oxidases. Contrib. Microbiol. 15, 164-187.

Rada, B. and Leto, T.L. 2009. Redox warfare between airway epithelial cells and Pseudomonas: dual oxidase versus pyocyanin. Immunol. Res. 43, 198-209.

Rada, B. and Leto, T.L. 2010. Characterization of hydrogen peroxide production by DUOX in bronchial epithelial cells exposed to Pseudomonas aeruginosa. FEBS Lett. 584, 917-922.

Rada, B., Park, J.J., Sil, P., Geiszt, M., and Leto, T.L. 2014b. NLRP3 inflammasome activation and interleukin- $1 \beta$ release in macrophages require calcium but are independent of calcium-activated NADPH oxidases. Inflamm. Res. 63, 821-830.

Reiter, B. 1978. The lactoperoxidase-thiocyanate-hydrogen peroxide antibacterium system. Ciba Found. Symp. 65, 285-294.

Rigutto, S., Hoste, C., Grasberger, H., Milenkovic, M., Communi, D., Dumont, J.E., Corvilain, B., Miot, F., and De Deken, X. 2009. Activation of dual oxidases DUOX1 and DUOX2: Differential regulation mediated by camp-dependent protein kinase and protein kinase C-dependent phosphorylation. J. Biol. Chem. 284, 6725-6734.

Rokutan, K., Kawahara, T., Kuwano, Y., Tominaga, K., Nishida, K., and Teshima-Kondo, S. 2008. NOX enzymes and oxidative stress in the immunopathology of the gastrointestinal tract. Semin. Immunopathol. 30, 315-327.

Roy, J., Galano, J.M., Durand, T., Le Guennec, J.Y., and Lee, J.C. 2017. Physiological role of reactive oxygen species as promoters of natural defenses. FASEB J. 31, 3729-3745.

Ryu, J.C., Kim, M.J., Kwon, Y., Oh, J.H., Yoon, S.S., Shin, S.J., Yoon, J.H., and Ryu, J.H. 2017. Neutrophil pyroptosis mediates pathology of $P$. aeruginosa lung infection in the absence of the NADPH oxidase NOX2. Mucosal Immunol. 10, 757-774.

Salathe, M., Holderby, M., Forteza, R., Abraham, W.M., Wanner, A., and Conner, G.E. 1997. Isolation and characterization of a peroxidase from the airway. Am. J. Respir. Cell Mol. Biol. 17, 97-105. 
Schwarzer, C., Machen, T.E., Illek, B., and Fischer, H. 2004. NADPH oxidase-dependent acid production in airway epithelial cells. $J$. Biol. Chem. 279, 36454-36461.

Segal, A.W. 2005. How neutrophils kill microbes. Annu. Rev. Immunol. 23, 197-223.

Shao, M.X. and Nadel, J.A. 2005. Dual oxidase 1-dependent MUC5AC mucin expression in cultured human airway epithelial cells. Proc. Natl. Acad. Sci. USA 102, 767-772.

Simmons, J.H., Purdy, G.A., Franklin, C.L., Trottier, P., Churchill, A.E., Russell, R.J., Besch-Williford, C.L., and Riley, L.K. 2002. Characterization of a novel parainfluenza virus, caviid parainfluenza virus 3 , from laboratory guinea pigs (Cavia porcellus). Comp. Med. 52, 548-554.

Sirokmany, G., Donko, A., and Geiszt, M. 2016. NOX/DUOX family of NADPH oxidases: Lessons from knockout mouse models. Trends Pharmacol. Sci. 37, 318-327.

Sommer, F. and Backhed, F. 2015. The gut microbiota engages different signaling pathways to induce DUOX2 expression in the ileum and colon epithelium. Mucosal. Immunol. 8, 372-379.

Song, Y., Ruf, J., Lothaire, P., Dequanter, D., Andry, G., Willemse, E., Dumont, J.E., Van Sande, J., and De Deken, X. 2010. Association of DUOXes with thyroid peroxidase and its regulation in thyrocytes. J. Clin. Endocrin. Metabol. 95, 375-382.

Sorce, S., Stocker, R., Seredenina, T., Holmdahl, R., Aguzzi, A., Chio, A., Depaulis, A., Heitz, F., Olofsson, P., Olsson, T., et al. 2017. NADPH oxidases as drug targets and biomarkers in neurodegenerative diseases: What is the evidence? Free Radic. Biol. Med. 112, 387-396.

Soukka, T., Lumikari, M., and Tenovuo, J. 1991. Combined inhibitory effect of lactoferrin and lactoperoxidase system on the viability of Streptococcus mutans, serotype c. Scand. J. Dent. Res. 99, 390-396.

Steiner, I. 2011. Herpes simplex virus encephalitis: New infection or reactivation? Curr. Opin. Neurol. 24, 268-274.

Stephens, S., Harkness, R.A., and Cockle, S.M. 1979. Lactoperoxidase activity in guinea-pig milk and saliva: Correlation in milk of lactoperoxidase with bactericidal activity against Escherichia coli. Br. J. Exp. Pathol. 60, 252-258.

Strengert, M., Jennings, R., Davanture, S., Hayes, P., Gabriel, G., and Knaus, U.G. 2014. Mucosal reactive oxygen species are required for antiviral response: Role of DUOX in influenza a virus infection. Antioxid. Redox Signal. 20, 2695-2709.

Suzuki, S., Ogawa, M., Ohta, S., Nunomura, S., Nanri, Y., Shiraishi, H., Mitamura, Y., Yoshihara, T., Lee, J.J., and Izuhara, K. 2016. Induction of airway allergic inflammation by hypothiocyanite via epithelial cells. J. Biol. Chem. 291, 27219-27227.

Szanto, I., Rubbia-Brandt, L., Kiss, P., Steger, K., Banfi, B., Kovari, E., Herrmann, F., Hadengue, A., and Krause, K.H. 2005. Expression of NOX1, a superoxide-generating NADPH oxidase, in colon cancer and inflammatory bowel disease. J. Pathol. 207, 164-176.

Tanaka, T., Murakami, S., Kumura, H., Igarashi, I., and Shimazaki, K. 2006. Parasiticidal activity of bovine lactoperoxidase against Toxoplasma gondii. Biochem. Cell. Biol. 84, 774-779.

Targovnik, H.M., Citterio, C.E., and Rivolta, C.M. 2017. Iodide handling disorders (NIS, TPO, TG, IYD). Best Pract. Res. Clin. Endocrinol. Metab. 31, 195-212.

Tenovuo, J. and Knuuttila, M.L. 1977a. The antibacterial action of the various components of the lactoperoxidase system on a cariogenic strain of Streptococcus mutans. J. Dent. Res. 56, 1603-1607.

Tenovuo, J. and Knuuttila, M.L. 1977b. Antibacterial effect of salivary peroxidases on a cariogenic strain of Streptococcus mutans. J. Dent. Res. 56, 1608-1613.

Tenovuo, J., Makinen, K.K., and Sievers, G. 1985. Antibacterial effect of lactoperoxidase and myeloperoxidase against Bacillus cereus. Antimicrob. Agents Chemother. 27, 96-101.
Thomas, E.L. and Aune, T.M. 1978a. Lactoperoxidase, peroxide, thiocyanate antimicrobial system: Correlation of sulfhydryl oxidation with antimicrobial action. Infect. Immun. 20, 456-463.

Thomas, E.L. and Aune, T.M. 1978b. Susceptibility of Escherichia coli to bactericidal action of lactoperoxidase, peroxide, and iodide or thiocyanate. Antimicrob. Agents Chemother. 13, 261-265.

Thomas, E.L., Milligan, T.W., Joyner, R.E., and Jefferson, M.M. 1994. Antibacterial activity of hydrogen peroxide and the lactoperoxidase-hydrogen peroxide-thiocyanate system against oral streptococci. Infect. Immun. 62, 529-535.

Touch, V., Hayakawa, S., Yamada, S., and Kaneko, S. 2004. Effects of a lactoperoxidase-thiocyanate-hydrogen peroxide system on Salmonella enteritidis in animal or vegetable foods. Int. J. Food Microbiol. 93, 175-183.

Tsalenchuck, Y., Tzur, T., Steiner, I., and Panet, A. 2014. Different modes of herpes simplex virus type 1 spread in brain and skin tissues. J. Neurovirol. 20, 18-27.

Ueyama, T., Sakuma, M., Ninoyu, Y., Hamada, T., Dupuy, C., Geiszt, M., Leto, T.L., and Saito, N. 2015. The extracellular a-loop of dual oxidases affects the specificity of reactive oxygen species release. J. Biol. Chem. 290, 6495-6506.

van der Hoeven, R., Cruz, M.R., Chavez, V., and Garsin, D.A. 2015. Localization of the dual oxidase BLI-3 and characterization of its NADPH oxidase domain during infection of Caenorhabditis elegans. PLoS One 10, e0124091.

van der Vliet, A. 2008. NADPH oxidases in lung biology and pathology: Host defense enzymes, and more. Free Radic. Biol. Med. 44, 938-955.

Virion, A., Michot, J.L., Deme, D., Kaniewski, J., and Pommier, J. 1984. NADPH-dependent $\mathrm{H}_{2} \mathrm{O}_{2}$ generation and peroxidase activity in thyroid particular fraction. Mol. Cell. Endocrin. 36, 95-105.

Wang, H. and Hartnett, M.E. 2017. Roles of nicotinamide adenine dinucleotide phosphate (NADPH) oxidase in angiogenesis: Isoform-specific effects. Antioxidants (Basel) 6, 40.

Weber, G., Rabbiosi, S., Zamproni, I., and Fugazzola, L. 2013. Genetic defects of hydrogen peroxide generation in the thyroid gland. J. Endocrinol. Invest. 36, 261-266.

Welk, A., Meller, C., Schubert, R, Schwahn, C., Kramer, A., and Below, H. 2009. Effect of lactoperoxidase on the antimicrobial effectiveness of the thiocyanate hydrogen peroxide combination in a quantitative suspension test. BMC Microbiol. 9, 134.

Welliver, R.C.Sr., Checchia, P.A., Bauman, J.H., Fernandes, A.W., Mahadevia, P.J., and Hall, C.B. 2010. Fatality rates in published reports of RSV hospitalizations among high-risk and otherwise healthy children. Curr. Med. Res. Opin. 26, 2175-2181.

Whitley, R.J. 2006. Herpes simplex encephalitis: Adolescents and adults. Antiviral Res. 71, 141-148.

Wijkstrom-Frei, C., El-Chemaly, S., Ali-Rachedi, R., Gerson, C., Cobas, M.A., Forteza, R., Salathe, M., and Conner, G.E. 2003. Lactoperoxidase and human airway host defense. Am. J. Respir. Cell. Mol. Biol. 29, 206-212.

Wittek, A.E., Yeager, A.S., Au, D.S., and Hensleigh, P.A. 1984. Asymptomatic shedding of herpes simplex virus from the cervix and lesion site during pregnancy. Correlation of antepartum shedding with shedding at delivery. Am. J. Dis. Child 138, 439-442.

Wong, J.L., Creton, R., and Wessel, G.M. 2004. The oxidative burst at fertilization is dependent upon activation of the dual oxidase UDX1. Dev. Cell. 7, 801-814.

Yang, X., Smith, A.A., Williams, M.S., and Pal, U. 2014. A dityrosine network mediated by dual oxidase and peroxidase influences the persistence of lyme disease pathogens within the vector. J. Biol. Chem. 289, 12813-12822.

Zheleva, A., Michelot, D., and Zhelev, Z.D. 2000. Sensitivity of alphaamanitin to oxidation by a lactoperoxidase-hydrogen peroxide system. Toxicon 38, 1055-1063. 